\title{
ERISA'S TITLE IV AND THE MULTIEMPLOYER PENSION PLAN
}

The Employee Retirement Income Security Act $^{1}$ has required tremendous changes in many pension plans. For inultiemployer plans, typically organized under the Taft-Hartley Act, ${ }^{2}$ the most significant changes were ERISA-mandated guarantees of pension benefits under ERISA's Title IV. ${ }^{3}$ Title IV created an insurance system designed to protect employees against the loss of their pensions. For the first time, employers were made statutorily hable for pension benefits if the pension fund was unable to pay a full pension benefit to the employees.

Sponsoring employers have found the obligations imposed by Title IV difficult to accept, and some believe that the pension plans are being adversely affected contrary to ERISA's goals. Employers therefore have challenged both the applicability of Title IV's provisions to multiemployer plans and the constitutionahty of its liability-imposing features. At the same time, in the wake of predictions that Title IV as written will contribute to plan failure rather than protect employees, a

THE FOLLOWING CITATIONS WILL BE USED IN THIS NOTE:

Employee Retirement Income Security Act of 1974, Pub. L. No. 93-406, 88 Stat. 829 (codified m scattered sections of $5,18,29,31,42$ U.S.C.) [heremafter cited by session law sections of ERISA];

S. 1076, 96th Cong., 1st Sess. (1979), 125 ConG. Rec. S5309 (daily ed. May 3, 1979) theremafter cited as S. 1076];

Brief for Appellees, Connolly v. PBGC, 581 F.2d 729 (9th Cir. 1979) [hereinafter cited as Brief for Appellees];

Subcomm. on labor of Senate Comm. on Labor and Pub. Welfare, 94th Cong., 2d Sess., Legislative History of the Employee Retirement Income Security Act of 1974 (1976) (3 vols.) [hereinafter cited as LEG. HIST.];

N. LeVIN, ERISA AND LABOR MANAgement BENefit Funds (rev. 2d ed. 1975) [hereinafter cited as N. LEVIN];

D. McGill, Fundamentals of Private Pensions (3d ed. 1975) [hereinafter cited as D. MCGILL];

J. Melone, Coltectively Bargained Mutli-employer Pension Plans (1963) [heremafter cited as J. MELoNe];

Pension Benefit Guaranty Corp., Multiemployer Study Required by P.L. 95-214 (1978) [hereinafter cited as PBGC STUDY];

Davis, Multiemployer Pension Plan Provisions in 1973, Monthly Lab. Rev., Oct. 1974, at 10 [hereinafter cited as Davis];

Hochman, The Supreme Court and the Constitutionality of Retroactive Legislation, 73 HARv. L. REv. 692 (1960) [hereinafter cited as Hochman].

1. 29 U.S.C. $\S \S 1001-1381$ (1976).

2. Id. $\S \S 141-188$.

3. Id. $\S \S 1301-1381$. 
debate continues over the wisdoin of applying Title IV's provisions to Taft-Hartley plans. This Note examines these challenges.

\section{Multiemployer Pension Plans: An Introduction}

\section{A. Characteristics of Multiemployer Taft-Hartley Plans.}

In the United States there are approximately 2,000 multiemployer pension plans ${ }^{4}$ covering nearly eight million employees, or about twenty-five percent of all workers covered under private pension plans. ${ }^{5}$ Of these inultiemployer plans, the inost significant type is organized pursuant to a collective bargaming agreement $\mathrm{m}$ which a group of einployers agrees to contribute to a trust fund administered jointly by union and employer representatives. ${ }^{6}$ Plans of this kind are known as Taft-Hartley trusts because section 302 of the Taft-Hartley Act governs their operation. ${ }^{7}$ Such plans are popular in the construction, mining, apparel and service industries, motor and water transportation, and wholesale and retail trade. ${ }^{8}$ In the 1960s and 1970s the number of participants in multiemployer plans increased at twice the rate of single employer plans, resultimg in the coverage under multiemployer plans of a progressively larger proportion of all pension plan participants.9 While soine of the largest plans are nationally organized, other plans

4. The standard definition of a multiemployer plan is a "plan which covers the employees of two or more financially unrelated employers." J. MELONE 1. See also D. MCGILL 78. For ERISA's purposes, a multiemployer plan is one maintained pursuant to a collective bargaining agreement requiring the contributions of more than one employer. If any one employer's contributions for the plan year comprise $50 \%$ or more of the aggregate contributions for the year, the plan is not a multiemployer plan under ERISA's definition. 29 U.S.C. $\$ 1002(37)(A)$ (1976). Once a plan achieves multiemployer status, the percentage contributed by any one employer may rise to $75 \%$. 29 U.S.C. § 1002(37)(B) (1976). See also T.D. 7552, 1978-2 C.B. 158. The PBGC has proposed revisions of this definition. See note 220 infra.

5. PBGC STUDY 20.

6. Id. 21; see N. LEviN 16-17, 33-34. Given the dominance of this form of organization, much of the hiterature treats the term "Inultiemployer plan" as synonymous with "Taft-Hartley trust." The lack of precision in these terms creates particular difficulty in determining the kind of plans included in various numerical estimates of the participants in "multiemployer plans." To be precise, the plans discussed in this Note must be described as private, collectively bargained, multiemployer, jointly administered pension plans. This Note will employ the terms "Taft-Hartley plan" and "multiemployer plan" to describe these plans.

7. 29 U.S.C. $\S 186(\mathrm{c})(5)(1976)$.

8. Davis 10 . In construction, for exaunple, about $95 \%$ of the 2.5 million pension plan participants are covered by multiemployer plans. Davis, Pension Plan Provisions in the Construction Industry, 1973, MONTHLY LAB. REv., Mar. 1975, at 63. The industries in which such plans predominate are commonly ones im which employees move from employer to employer with great frequency, often through hiring hall arrangeinents. See text accompanying note 31 infra.

9. E. Allen, J. Melone \& J. Rosenbloom, Pension Planning 18 (3d ed. 1976); Davis 10. See text accompanying notes 24-33 infra for a discussion of the reasons for the rapid growth of these plans. 
are locally or regionally based because of union or industry characteristics. ${ }^{10}$

The Taft-Hartley Act prohibits payment of inoney by einployers to labor organizations. ${ }^{11}$ This provision stopped the negotiation of pension agreements under which employers agreed to pay money into pension funds run by the union, to avoid "the possible abuse by union officers of the power which they might achieve if welfare funds were left to their sole control."12 As an alternative, the Act allows pension and welfare plan contributions to a trust fund if the trust: (1) is created for the "sole and exclusive benefit" of the employees; (2) is administered by a joint board with an equal number of employer and employee representatives, plus neutral parties they agree on; (3) is formed for limited purposes (includimg pension) enumerated in the Act; (4) is governed pursuant to a written agreement specifying in detail the basis upon which the employer shall inake payments; (5) is audited annually; and (6) provides for arbitration in case of deadlock. ${ }^{13}$

After the employers and union agree to create a pension plan ${ }^{14}$ and complete a trust agreenent, a two-step procedure is followed to fund the plan and to fix benefit levels. The first step is to negotiate a fixed rate of employer contribution to the trust fund. This rate is usually an amount per hour of employinent or per unit of production, such as per ton of coal mined. ${ }^{15}$ In the second step, the trustees meet and set benefit levels, first by estinnating the fund's income-consisting of employer contributions and investment income-and the fund's expenses, and then coinputing the maximuin benefit the fund can afford to pay. ${ }^{16}$ This computation requires actuarial estinates of the probable demands

10. D. MCGILL 79. In 1973, 10 large plans with over 100,000 participants accounted for onethird of all multiemployer plan participants, including "[a] few large national plans, such as those in the construction industry, and regional plans, such as the Western Conference of Teamsters plan ...." Davis 1.. See also PBGC STUDY app. II.

11. 29 U.S.C. \& 186(a) (1976).

12. Arroyo v. Umited States, 359 U.S. 419, 425-26 (1959). The abuses feared included use of funds "to perpetuate control of union officers, for pohtical purposes, or even for personal gain." Id. at 426. Pension funds created prior to January 1, 1946, were unaffected by the Act. 29 U.S.C. $\S 186(\mathrm{~g})(1976)$.

13. 29 U.S.C. § 186(c)(5) (1976); see N. LEvIN 4-5.

14. Pension benefits are mandatory subjects of collective bargaining. See Inland Steel Co. v. NLRB, 170 F.2d 247 (7th Cir. 1948), cert. denied, 336 U.S. 960 (1949), affd, 339 U.S. 382 (1950). Thus, during the term of a labor agreement, an employer cannot install, alter or terminate a pension plan for organized workers without the assent of the union. D. MCGILL 27. See, e.g., Wilson \& Sons, 193 N.L.R.B. 350 (1971). The pension benefits of retirees are not mandatory subjects of collective bargaining. Allied Chem. \& Alkali Workers v. Pittsburgh Plate Glass Co., 404 U.S. 157 (1971).

15. J. MELONE 97; Davis 10.

16. J. MELONE 49, 91. 
on the fund for benefits and a projection of income for the upcoming period. ${ }^{17}$ The benefit-setting process can take as long as two years if the trustees cannot agree on the appropriate benefit levels. ${ }^{18}$

Upon retirement, then, the employee does not simply receive the sun total of employer contributions on his or her behalf plus investinent income. Instead, the employee receives a benefit determined by the trustees' benefit formula. The formulas are of two basic kinds: the flat benefit, providing a uniform amount for all retirees; or a benefit formula based on length of service in the industry. ${ }^{19}$

The extent to which the plan achieves the desired balance between incoune and pension payments depends upon the accuracy of the actuarial projections, as compared to the actual experience of the plan. ${ }^{20}$ Prior to ERISA, trustees discovering that contributions were too low to support the plan benefits were free to lower the benefits, making termination of inultiemployer plans rare. ${ }^{21}$ Alternatively, or in conjunction with lowering the benefits, higher contribution rates could be sought at the next contract negotiation. ${ }^{22}$ It is, however, important to note that such plans invariably included provisions stating that no employer bore liability for the benefits promised by the trustees; the employer's only obligation was to make the contractual contributions to the trust fund. ${ }^{23}$ Thus, if for any reason the trust could not provide benefits at the levels promised, no action could be brought against the employer for the unpaid benefits.

\section{B. Advantages to Employers, Employees and Unions.}

The popularity of the multiemployer arrangement ${ }^{24}$ is attributable to the advantages it offers employers, employees and unions. First,

17. Important factors to be considered include the level of contributions, mortality rates, enployee turnover, retirement age, salary scales, investment experience and administrative costs. J. Melone 76-87; F. Pomeranz, G. Ramsey \& R. Steinberg, Pensions 23-24 (1976). Umion efforts for high benefit rates, see D. MCGill 97, may focus on the choice of an actuary with a reputation for recommending high benefits. See J. MELONE 10.

18. See J. Melone 10-11.

19. See id. 20-21; Davis 12. The service-related formulas predominate in construction, printing, inotor transport, metalworking and service industries, while fiat benefits prevail in apparel, mining and transportation. J. MELONE 12-13. Unions may prefer the service-related formula because of its greater ability to provide some benefit no inatter how long an employee has served. See id. 21-22. This contrasts with single einployer plans, which often base benefits on earnings. In unionized employment there is less variation in earning levels than in nonunion employment; further, the plans can avoid recordkeeping burdens by excluding this factor. Davis 12.

20. J. Melone 51 .

21. See text accoinpanying note 174 infra.

22. J. Melone 51, 94; Davis 10.

23. J. Melone 49; PBGC Study 2-3.

24. See notes 4-5, 9-10 supra and accompanying text. 
given the industries involved ${ }^{25}$ and the nature of the employment, multiemployer plans are the most desirable, if not the sole means of providing pension benefits. ${ }^{26}$ These industries are highly competitive; without the uniform negotiated contribution rate applying equally to all employers in the trade, single employers would be less likely to commit themselves to pensions, fearing costs not faced by competition. ${ }^{27}$ Further, these industries often consist of smaller employers for whom the costs of negotiating and administering single employer plans could be excessive. ${ }^{28}$ The nultienuployer arrangement allows cost-sharing; in addition, the actuarial predictions will be more accurate with a greater nuinber of employees involved. ${ }^{29}$ The broader-based multiemployer plan also avoids einployee rehance on the ability of these small employers in competitive industries to stay in busmess. ${ }^{30}$ Finally, when the einployees inove froin employer to employer, conventional single einployer pensions are impossible. ${ }^{31}$ Instead, the multiemployer plans are organized around the employees' common bond of union membership.

In summary, the employer gets a plan that combines desired uniform contribution rates, with hability limited to those contributions, ${ }^{32}$ and the advantages of a single-plan administration. The union gets a pension plan with uniform benefit rates for all of its members, and it can use that plan as an attraction for employees in representation efforts. ${ }^{33}$ The employee gams a pension arrangeinent, with the usual advantages of retirenient income and deferred income tax advantages, despite the lack of einployinent by a single einployer and without relying on the economic success of any one employer.

25. See note 8 supra and accompanying text.

26. It is assumed here that employees, unions and employers find pension plans desirable if they are feasible. See text accompanying notes 28-33 infra for incentives favoring adoption of pension plans.

27. A contractor preparing a competitive bid is an example of an employer who would find these costs disadvantageous if such pension plans were not common among others in the trade.

28. J. Melone 6-7, 90-91.

29. N. LEVIN 33; J. MELONE 7-8.

30. J. MELONE 8. If, however, the entire industry is in decline, the multieinployer plan will be cqually unhealthy. See note 188 infra.

31. J. MELONE 8-9.

32. The same contribution rate is required of each enployer without reference to the cost factors of his own employee group. As a result, some employers inay pay more and others less than their share of the cost of benefits for their own employees. . . .

[T] he union is the cohesive force demanding that eniployers accept the plan's average experience in lieu of their own costs and offering a limitation of contribution liability as a quid pro quo.

Id. 95-96.

33. See id. 168-75. 


\section{ERISA's Provisions Regulating the Operation of Multiemployer Plans.}

ERISA's two principal goals were "[t]he growth and continuance of private pension plans and the security of workers' pension benefits."34 The Act contains various protective provisions that apply to multieinployer plans: vesting provisions require that benefits vest in the participants after statutorily prescribed periods; ${ }^{35}$ funding requirements insure that contributions are made and that the funds accumulated through contributions correspond to plan obhigations; ${ }^{36}$ fiduciary responsibility standards hold trustees to strict standards of performance; 37 and disclosure requirements provide participants with information about the plan. ${ }^{38}$

In addition, Title IV of ERISA created the Pension Benefit Guaranty Corporation (PBGC), an independent government corporation, to imsure einployee pension benefits. ${ }^{39}$ The PBGC collects insurance pre-

34. PBGC Study 48; see 29 U.S.C. $\$ 1001$ (a) (1976). See also In re C.D. Moyer Co. Trust Fund, 441 F. Supp. 1128, 1131 (E.D. Pa. 1977), affd, 582 F.2d 1273 (3d Cir. 1978).

35. Plans inay use one of three options for vesting of benefits. These include ten-year vesting, five-to-fifteen-year vesting, and the "Rule of 45" (a rule under which employees with five or more years of service must be at least $50 \%$ vested when the sum of the einployee's age and years of service is 45). ERISA § 1012(a), I.R.C. § 411(a). For vesting purposes, all employers within a multieinployer plan are treated as a simgle employer. ERISA $\$ 1015$, I.R.C. $\$ 413(C)(3)$. The effect is to vest benefits on the basis of counbimed years of service by employees to any nember employer.

Prior to ERISA, about $60 \%$ of all multiemployer pension plans provided for vesting of benefits. Thirty percent of these followed the ten-year vesting rule, while others specified longer periods. Half of the vesting plans specified minimum age requirements. Davis 14-15. ERISA, then, forced changes in vesting procedures for the $40 \%$ that did not provide for vesting, as well as for those plans with vesting requirements that did not fall within the allowed options.

36. The funding requirements mclude special provisions for multiemployer plans. An ordinary defined benefit plan must maimtain a "funding standard account," im which employer payments equal normal costs of the benefits plus amortized past service costs and experience gains or losses. The Act and regulations require inultiemployer plans to follow this procedure but allow longer amortization periods. See ERISA $\$ \$ 302$, 1013(a). Further, multiemployer plans are allowed to use a "shortfall" accounting method that allows contributions on the basis of the contractually determined rate throughout the contract period even if the contributions prove to be lower than originally projected. At the end of the contract period, the amount actually contributed is coinpared with the amount normally required under the fimding standard account method. Any difference is a shortfall gain or loss, whieh is to be corrected by increasing or decreasing contributions at contract negotiation or by adjusting the benefit levels. The gain or loss is amortized over a fifteen-year period. 26 C.F.R. $\$ 11.412$ (c)(1)-(2) (1978). Failure to fund the account properly results either in an excise tax that is allocated among the employers, or in a civil action. I.R.C. $\$ \$ 413(b)(6), 4971$. The net effect is to enforce collection of the contributions and to insure that the contributions are sufficient to produce the benefit.

37. See 29 U.S.C. $\$ \$ 1101-1114$ (1976). For a discussion of fiduciary duties under ERISA, see Note, Fiduciary Standards and the Prudent Man Rule under the Employment [sic] Retirement Income Security Act of 1974, 88 HARV. L. REV. 960 (1975).

38. See 29 U.S.C. $\$ \$ 1021-1031$ (1976).

39. Although the funding provisions force sponsors to fund the pensions, the funding is not 
miums from the pension plans under Title IV's coverage ${ }^{40}$ and provides benefits to participants in those plans in the event the plan terminates with insufficient assets to support guaranteed benefits. ${ }^{41}$ Multiemployer plans are required to pay premiums of fifty cents per participant per year, although PBGC benefit insurance for such plans remaims discretionary until May 1, 1980. Mandatory coverage of multiemployer plans was delayed to allow the PBGC to ascertain its level of risk in insuring such plans. ${ }^{42}$

Upon plan termination the PBGC will allocate the assets of the plan in the statutorily prescribed manner. If the assets are imsufficient to pay the guaranteed benefits, the participating employers are liable to the PBGC for a proportionate segment of the deficit, up to a maximum of thirty percent of the employer's net worth. ${ }^{43}$ The focus on benefits

full and immediate. Instead, it is amortized over a period of years. Thus, the possibility remains that upon termination, the plan will have insufficient assets to pay the benefits promised. See 120 CONG. REC. 4282 (1974), reprinted in 2 LEG. HIST. 3382.

40. See 29 U.S.C. $\$ \S 1301-1307$ (1976); D. MCGILL 426-27.

41. Plans terminate in two ways. First, they may terminate voluntarily when plan administrators notify the PBGC of their intention to terminate the plan. See ERISA $\$ 4041$. In a TaftHartley plan, this requires an agreement between the union and the employers with regard to current employees' benefits. Second, the PBGC nuay force plan termination upon finding that (1) the plan has not inet the minimum funding standard or is deficient in payment of the excise tax imposed for deficiencies in funding; or (2) the plan is unable to pay benefits when due; or (3) the plan has made a contribution of $\$ 10,000$ or more to a "substantial owner" for reasons other than death, and immediately after this distribution the plan has unfunded nonforfeitable benefits; or (4) the PBGC feels that the risk of loss to PBGC will increase unreasonably unless the plan is terminated. 29 U.S.C. \$ 1342(a) (1976). The PBGC will guarantee nonforfeitable pension benefits to which the participant is entitled at the time of termination. 29 C.F.R. $\$ 2605$ (1978). The PBGC originally limited its paynent to the lesser of $\$ 750$ per inonth or a inonthly amount equal to onetwelfth of the average annual incoine during the five consecutive years when incoine was highest. 29 U.S.C. $\$ 1322(\mathrm{~b})(3)$ (1976). The $\$ 750$ amount has been adjusted for increases in the cost of living and is now at \$1073.86. [1978] 213 PENS. REP. (BNA) A-10. No benefit is paid for recent benefit increases or increases made while the plan was in default. The fact that the PBGC does not guarantee a given benefit does not mean that the participant will not receive any funds, since upon termination, plan assets are allocated to both nonguaranteed benefits and guaranteed benefits, in the order prescribed in 29 U.S.C. $\$ 1344$ (1976). If, after all funds have been distributed, some guaranteed benefits are still unpaid, the PBGC will pay then. The PBGC can, however, recover some or all of these funds from the employer. See note 43 infra and accompanying text. See generally M. CANaN, Qualified RetiRement Plans $\$ \$ 19.6-10$ (1977); D. MCGILL 429-49.

42. See 29 U.S.C. $\S 1381$ (c) (1976), as amended by Act of Dec. 19, 1977, Pub. L. No. 95-214, 91 Stat. 1501; Act of June 19, 1979, Pub. L. No. 96-24, 93 Stat. 70. This date is an 18-1nonth cxtension over the original ERISA provisions enacted because of Congress' fears of inultienployer plan tcrminations far in excess of the PBGC's ability to pay benefits. See PBGC STUDY 19. See text acconipanying note 187 infra. In the neantime, premiun funds are accumulating and have been used to provide discretionary coverage to several multienuployer plans that have terminated since the Act's passage. PBGC STUDY app. XV.

43. See 29 U.S.C. $\$ \S 1362,1364$ (1976). The specific formula for inultieinployer plans is as follows: For any employer who inade contributions within five years of plan termination, the anount required in contributions froin the employer for the past five years is divided by the total contributions required of all participating enployers; this figure is multiphed by the excess of 
rather than contributions means that the payment by the employer of all contractually required contributions is irrelevant. The capacity of the fund to pay the benefits set by the trustees is controlling. The PBGC is einpowered to obtain a lien similar to a tax lien against the einployers' assets or to initiate a civil action to obtain the funds. ${ }^{44}$

Einployers opposed to potential liability for benefits have atteinpted to escape Title IV's requirements. They mamtam, first, that the typical multiemployer plan is exempt from Title IV coverage. ERISA section 4021(b)(1)45 exempts "any plan which is an individual account plan" 46 froin Title IV's requirements. "Individual account plan" is defined earlier in the Act, along with "defined contribution plan":

The term "individual account plan" or "defined contribution plan" means a pension plan which provides for an individual account for each participant and for benefits based solely upon the amount contributed to the participant's account, and any income, expenses, gaims and losses, and any forfeitures of accounts of other participants which may be allocated to such participant's account. ${ }^{47}$

The PBGC maintains that Taft-Hartley pension plans do not fall within the statutory exception quoted above, and that such plans are therefore subject to all Title IV provisions, mcluding imposition of employer liability. Second, even if the plans are covered by Title IV, the plan sponsors contend that a retroactive change in the nature of the participating employers' commitment, obligatimg them to guarantee benefits, violates fifth amendment prohibitions agamst deprivation of property without due process of law. Finally, sliould both of the above arguments fail, plan sponsors argue that Title IV's provisions threaten the continued growth and existence of Taft-Hartley plans by ending or reducing the willingness of employers to participate in such plans or to increase their obligations under the plans.

guaranteed plan benefits over the assets of the plan at termination. That is, liability is a proportion of the guaranteed benefits not covered by plan assets equal to the employer's percentage of total contributions over the past five years. An employer's liability is limited to $30 \%$ of the employer's net worth. 29 U.S.C. $\$ 1323$ provides for creation of an insnrance program protecting employers against this liability. The PBGC has, however, conclnded that such an insurance program is not feasible at this time. See [1978] 195 PENs. REP. (BNA) R-6. See note 221 infra and accompanying text.

44. 29 U.S.C. $\$ 1368$ (1976). This lien, like a tax lien, enjoys priority over the unsecured claims of creditors. J. Treynor, P. Regan \& W. Priest, JR., The Financial. Reality of PenSION FUNDING UNDER ERISA 1 (1976).

45. 29 U.S.C. $\S 1321(\mathrm{~b})(1)(1976)$.

46. Id.

47. Id. $\$ 1002(34)$. 


\section{Title IV's Coverage of the Multiemployer Plan}

\section{A. Connolly v. Pension Benefit Guaranty Corp.}

In Connolly v. Pension Benefit Guaranty Corp. ${ }^{48}$ the trustees of a Taft-Hartley pension trust ${ }^{49}$ sought a declaratory judgment that the Operating Engineers' pension plan supported by the trust was not subject to ERISA's Title IV on the grounds that the plan fell within the exception for "individual account plans." 50 The trustees also requested an injunction to prohibit the collection of insurance premiums by the PBGC and to force the return of $\$ 12,043$ in prennums already paid. ${ }^{51}$

The plan in question was a typical multieinployer plan ${ }^{52}$ under which the einployers contractually agreed to contribute a specified anount ${ }^{53}$ to a jointly administered trust fund. ${ }^{54}$ Both the trust agreeinent and the pension plan specified that each employer's liability to the plan and to the employees was limited to the contributions required by the collective bargaining agreement, regardless of the ability of the fund to pay pension benefits to the employees. 55 The benefits paid to retirees were determined by the trustees, who periodically set a "pension factor" reflecting "investment imcome, gaims and losses, expenses, any forfeitures by participants, the inortality experience of the Plan and the actual anticipated employer contributions and delinquencies." 56 Upon retireinent, the "pension factor" was multiphed by figures reflecting the retiree's years of service to compute the retiree's monthly benefit. ${ }^{57}$

48. 419 F. Supp. 737 (C.D. Cal. 1976), rev'd and remanded, 581 F.2d 729 (9th Cir. 1978), cert. denied, 99 S. Ct. 1278 (1979).

49. The trust was created in a 1960 agreement between the International Union of Operating Engineers and various contraetors and home builders in southern California. $419 \mathrm{~F}$. Supp. at 737 .

50. 29 U.S.C. \& 1321(b)(1) (1976). See text accompanying note 46 supra.

51. 419 F. Supp. at 738.

52. Tilove, ERISA-Its Effect on Collective Bargaining, Proc. N.Y.U. TweNTY-NinTH Conf. LAB. 187, 193 (1976); see [1978] 187 Pens. Rep. (BNA) A-36.

53. In this plan the figure was two dollars per hour of employment. Brief for Appellees 4.

54. See text accompanying notes 13-18 supra.

55. [The Plan restricted employer liability to] the obligation of the Individual Employer to inake contributions as stipulated in any Collective Bargaining Agreement. ... [N]othing contained in this Pension Plan and the Trust Agreement shall be construed as obligating any Individual Employer to inake benefit payments or contributions (other than the contributions for which the Individual Employer may be obligated by any Collective Bargaining Agreement) in order to provide for the benefits established by the Pension Plan.

419 F. Supp. at 739. The district court's opinion states that the trustees could force einployers to increase their contributions if necessary to support the fund. $419 \mathrm{~F}$. Supp. at 740 . This was later identified as harmless error. Brief for Appellees 15.

56. 419 F. Supp. at 740. Actuaries determined the pension factor appropriate for the plan and the trustees adopted it on their advice. See note 17 supra and accompanying text.

57. Each enployee's years of service in the industry were computed on the basis of "prior service credits" granted for each year of covered service in the industry prior to the establishment 


\section{B. Exemption from Title IV as an Individual Account Plan: The Trustees' Argument.}

In their effort to have the Operating Engineers' pension plan declared exeinpt from ERISA's Title IV, the trustees in Connolly atteinpted to characterize the plan as an individual account plan exeinpt from Title IV. 58 The trustees faced two tasks: first, to show that the plan was a "defined contribution plan," which ERISA section 3(34) defines as identical to an imdividual account plan; 59 and second, to show that the plan was not one "under which a fixed benefit is proinised ... [and] the einployer or his representative participated in the determination of that benefit," since any plan having such a benefitdetermination system is not an individual account plan for Title IV purposes. ${ }^{60}$

The term "defined contribution plan," although not used in federal statutes or regulations prior to ERISA's passage, ${ }^{61}$ was used prior to ERISA as a standard means of distinguishing between two basic patterns of plan organization:

The first is called a defined contribution or a money purchase formula. Under this type of formula, contribution rates are fixed, and an employee's benefit varies depending upon such factors as the amount of the contributions made, imvestment earnings or plan assets, and the employee's age, sex and normal retirement age. The second type is called a defined benefit or an annuity purchase formula. Here, a defimite benefit is established for each employee, and contributions are determined to be whatever is necessary to produce the desired benefit results. ${ }^{62}$

In other words, a defined contribution plan provides for a fixed input and allows the output to vary, while the defined benefit plan provides for a fixed output and varies the input. ${ }^{63}$

of the plan in 1960, and "pension credits" earned whenever the employee worked for a set number of hours. 419 F. Supp. at 741.

58. 29 U.S.C. $\$ 1321$ (b) (1976). See text accompanying note 46 supra.

59. 29 U.S.C. $\S 1002(34)$ (1976). See text accompanying note 47 supra.

60. 29 U.S.C. § 1321(c)(1) (1976).

61. I. Goodman, Defined Contribution Plans Under erisa 11 (Pens. Plan Guide) (CCH) No. 197 (1979).

62. E. ALLEN, supra note 9, at 31.

63. See generally M. CANAN, supra note 41, § 3.51, at 89-90; D. MCGILl 91-109; J. Melone 48-51. In Alabama Power Co. v. Davis, 431 U.S. 581,593 n.18 (1977), the Court characterized the pension plan under consideration as a defined benefit plan simce "the benefits to be received by einployees are fixed and the employer's contribution is adjusted to whatever level is necessary to provide those benefits." The Court contrasted this plan with a defined contribution plan, "[t]he other basic type of pension ... under which the employer's contribution is fixed and the employee receives whatever level of benefits the amount contributed on his behalf will provide." 431 U.S. at 593 n.18. ERISA's provisions were not at issue here, although the Court cited 29 U.S.C. $\S 1002(34)-(35)$ in support of the above statement. See notes $88 \& 91$ infra. 
The trustees contended that since their plan used a fixed contribution rate and varied the benefits through use of the pension factor, it met the basic requirements of a defined contribution plan. ${ }^{64}$ Aside from this general definitional comphance, the trustees argued that the plan satisfied the "individual account" requirements of section 3(34) because computerized records were kept indicating each employee's hours of employment as well as the contributions that those hours obhgated the einployer to pay on the employee's behalf. ${ }^{65}$ Although the employee did not receive these contributions directly on an individual account basis, each employee was assigned service credits corresponding to the hours worked. The hours worked, in turn, corresponded to the amount contributed by the employer. Before paymg benefits, the plan then accounted for plan experience, including investment income, by multiplying the service credits by the "pension factor." 66 The trustees mamtained that through this process benefits in effect were based solely on contributions plus gams or losses from plan experience-with no resort to employer funds beyond the contributions. Thus, the plan met the statutory requirement of "benefits based solely upon the amount contributed to the participant's account, and any imcome, expenses, gains or losses . . . ."67

From the trustees' viewpoint, any greater "individualization" of accounts would create savings accounts, not pension plans. Since section 3(34) deals only with "pension plans," 68 the requirement of individual accounts, taken in context, must refer to something similár to the arrangement in the Operating Engineers' plan.

Conceding that the legislative history of ERISA contains no exphicit declaration that plans like the Operating Engineers' plan were to be exempt from Title IV's termination insurance, the trustees attempted to shift the burden by insisting that if truly drastic changes in employer obligations ${ }^{69}$ were intended, exphicit congressional statements would appear in the record. In the absence of such clear intent, the trustees argued that Congress excluded plans like theirs from the benefit insurance program, along with all other plans that promise no fixed benefit but only a fixed contribution. ${ }^{70}$ The employee was promised nothing

64. Brief for Appellees 9.

65. Id. 7-8, 27.

66. Id. 8-9.

67. 29 U.S.C. § 1002(34) (1976).

68. Id.; see Brief for Appellees 26-27.

69. See notes 116-20 infra and accompanying text.

70. The legislative history indicates that the plans not requiring insurance protection were "money purchase, stock bonus, or profit sharing plans." S. REP. No. 93-383, 93d Cong., lst Sess. 26 (1973), reprinted in 1 LEG. HisT. 1063, 1094. Because these plans "do not provide specific 
more than his share of the accumulated fund after employer contributions were made and adjustments made for gams and losses; the government, therefore, had no reason to msure the payment of a fixed benefit. $^{71}$

To overcome the language of ERISA section $4021(\mathrm{c})(1),{ }^{72}$ the trustees argued that imstead of "fixed benefits," their plan had variable benefits depending upon the "pension factor" adopted by the trustees. Further, even if the benefit were regarded as "fixed" they contended the benefit was set not by an "employer or his representatives," but by trustees who had a fiduciary duty to the trust independent of any responsibility to the union or employers who named them as trustees. ${ }^{73}$

The federal district court accepted the trustees' imterpretation of Title IV. Relying particularly on the distimction between defined benefit and defined contribution plans, the court emphasized the employers' fixed contribution obligation and their limited hability, notimg that

previously determined benefits, there is no defined benefit to insure." Id. 1094. This is illustrated by examination of the exeinption clauses in the earlier versions of Title IV. See; e.g., S. 4, 93d Cong., 1st Sess. § 104(c) (1973), reprinted in 1 LEG. HisT. 113; S. 1179, 93d Cong., 1st Sess. $\S 421$ (c)(1) (1973), reprinted in 1 LEG. HIST. 907; H.R. 12,906, 93d Cong., 2d Sess. $\$ \$ 301$ (c), 409 (1974), reprinted in 2 LEG. HIST. 2860, 2885-86.

71. In effect, the employee stands to gaim in benefits if the fund performs well and also bears all risk if it does not. See Note, supra note 37, at 962-63.

72. 29 U.S.C. $\$ 1321(c)(1)$ (1976). See text accompanying note 60 supra.

73. Brief for Appellees 32. In Sheet Metal Workers Local 493, 234 N.L.R.B. No. 162 (1978), the Board held that a strike to compel einployer acceptance of certain trustees as einployer representatives was not a violation of 29 U.S.C. $\$ 158(\mathrm{~b})(\mathrm{l})(\mathrm{B})$ 's prohibition against coercion in the selection of collective bargaining agents. The Board reasoned that given the independent duties owed by plan trustees to the trust and the separation of the benefit-determining process from collective bargaining, the trustees were not agents of the einployers. Cases support the existence of a fidnciary duty toward the trust, and this duty, while not excluding the possibility of union or employer influence or suggestions to the trustees, is superior to any duty toward the union or employer. See Toensing v. Brown, 528 F.2d 69, 72 (9th Cir. 1975) (trustee duty to exercise independent judgment recognized); Lamb v. Carey, 498 F.2d 789, 793 (D.C. Cir. 1974) (trustees have high fiduciary responsibility to the fund despite representative relationship); Miniard v. Lewis, 387 F.2d 864, 865 n.5 (D.C. Cir.), cert. denied, 393 U.S. 873 (1967) (union trustees free of duty to union but owe duty to trust); Kosty v. Lewis, 319 F.2d 744 (D.C. Cir. 1963) (superior fiduciary duty to trust recognized); Blankenship v. Boyle, 329 F. Supp. 1089, 1094-95 (D.D.C. 1971) (section 302 designed to insulate trust from labor-management disputes and strengthen independent duty to trust); $c f$. Associated Contractors v. Laborers Int'1 Umion, 559 F.2d 222, 228 (3d Cir. 1977) (co-existing duty of representation and fiduciary responsibility). See also Welch \& Wilson, Application of Trust Law to Representatives in Taft-Hartley Trust Funds, 28 ARB. J. 81, 93-94 (1973) (supporting the view that the fiduciary duty should be strict, and that any decisions the parties do not want judged on a strict fiduciary standard should be made at the collective bargaiming table). (Cf. Goetz, Employee Benefit Trusts Under Section 302 of Labor Management Relations $A C t, 59$ Nw. U.L. REV. 719, 748 (1965) (arguing that imclusion of employer and union representatives in the trust administration indicates Congress' recogmition that divergent interests will be represented and not excluded by fiduciary principles); Goetz, Developing Federal Labor Law of Welfare and Pension Plans, 55 CoRnell L. Rev. 911, 921-25 (1970) (trustee deliberations are extension of collective bargaining process). 
"[t]o interpret this carefully constructed agreement as not coming within the exceptions . . . is to force upon the employer a greater obligation and liability than he had agreed to in his contract." 74 On these grounds, the court characterized the plan as a defined contribution plan. The PBGC's arguments to the contrary were dismissed without explanation. ${ }^{75}$ As for ERISA section $4021(c)(1),{ }^{76}$ the court held that the benefits had been determined not by an employer or his representatives but by the trustees. ${ }^{77}$ Thus, the plan was considered an individual account plan for Title IV purposes, and exempt from the Title's coverage.

\section{Coverage of Multiemployer Plans Under Title IV: Denial of "Individual Account" Status.}

The Ninth Circuit Court of Appeals reversed the district court in Connolly, holding that the Operating Engmeers' plan did not provide for individual accounts and therefore was not exempt from Title IV. ${ }^{.8}$ The case was remanded for consideration of the trustees' constitutional challenges to liability for benefits. ${ }^{79}$ In two similar disputes, Umited States district courts read the statute in the same manner as the Nimth Circuit, holding that the plans in question were not individual account plans and were subject to Title IV. ${ }^{80}$

The Ninth Circuit's strict reading of the language of ERISA section $3(34)^{81}$ made it very difficult to come within the "individual account" exception. The court required a showing of both imdividual accounts for each participant and benefits based solely on the amounts in these accounts in order to escape Title IV. ${ }^{82}$ The Operating Engineers' plan pooled its funds and neither recorded the amounts contributed on the behalf of each employee nor recognized the participants' "right, title, or interest"83 to any amount im an account. Thus, no individual accounts existed. Further, benefits were not determined solely

\footnotetext{
74. 419 F. Supp. at 740.

75. $I d$. at 741 .

76. 29 U.S.C. $\$ 1321(c)(1)$ (1976). See text accompanying note 60 supra.

77. $419 \mathrm{~F}$. Supp. at 741 .

78. Connolly v. PBGC, 581 F.2d 729, 735 (9th Cir. 1978). Having concluded that the plan did not create individual accounts, the court did not reach the trustees' claim that ERISA $\S 4021(c)(1)$ was inapplicable.

79. 581 F.2d at 734-35.

80. Pierce v. PBGC, No. 77-C-4194 (E.D. Ill., filed June 18, 1979); PBGC v. Defoe Shipbuilding Co., [1978] 178 PENS. REP. (BNA) D-15 (E.D. Mich.), appeal docketed, No. 78-1280 (6th Cir. Aug. 7, 1978).

81. See text accompanying note 47 supra.

82. 581 F.2d at 733 .

83. Id.
} 
by the ainounts in the accounts; rather, benefits were computed on the basis of service, past service and the pension factor. ${ }^{84}$

This approach recognized what is clearly true, at least technically: a mere recording of hours employed and consequent employer contribution obligations does not create an imdividual account similar to a bank savings account. Nevertheless, if the employee's hourly service determines the ainount contributed by the employer, ${ }^{85}$ in a functional sense the service figure is a recording of the amount in the individual's pension account. Then, if the amount paid in benefits simply reflects the ainount of inoney contributed for the hours of work, adjusted to reflect income and costs of the plan as a whole, 86 "individual accounts" exist.

The difficulty with the Operating Engmeers' plan and similar plans is that the hours of employment and employer contributions are not the sole basis for determining the benefit: the plan allowed participants to obtain benefits on the basis of past service for which no employer contributions capable of individual assignment were made. ${ }^{87}$ Thus, the relationship between individual service, individual contributions and individual benefits was broken by allowing the payment of benefits for service for which there were no corresponding contributions. The Ninth Circuit's approach recognized this flaw and derned the plan the individual account designation. ${ }^{88}$ Since the typical negotiated inultieinployer plan determines benefits on the basis of service, without reference to contributions, ${ }^{89}$ this holding would apparently have widespread application.

The result reached on the basis of a strict reading of the statutory language could be avoided only by concluding that Congress intended a broader exemption than a technical reading of the statute permits. If, by using the term "defined contribution plan" with its known pre-ER-

84. Id.

85. See note 57 supra.

86. This is the function of the pension factor in the Operating Engineers' plan. See note 57 supra and accompanying text.

87. See note 57 supra. Although it is arguable that einployer contributions for past service were unade on the grounds that every employer's hourly contribution paid part of the total past service liability, there is no way of knowing whether such amounts were contributed, and on whose behalf the contributions were inade.

88. $581 \mathrm{~F} .2 \mathrm{~d}$ at 733 . In describing the inultieinployer pension plan at issue in International Bhd. of Teamsters v. Daniel, 99 S. Ct. 790 (1979), as a defined benefit plan, the Supreine Court observed that "[t]he trust agreeinent used employee inanweeks as a convenient way to ineasure an einployer's overall obligation to the Fund, not as a ineans of measuring the employer's obligation to any particular employee. Indeed, there was no fixed relationship between contributions to the Fund and an employee's potential benefits." Id. at 797. See note 91 infra. This plan also recognized past service as a factor in determining benefits. $99 \mathrm{~S}$. Ct. at $797 \mathrm{n} .13$.

89. See J. Melone 20. See note 19 supra and accompanying text. 
ISA meaning, ${ }^{90}$ Congress meant to express a general intent to declare a Title IV exemption for all multiemployer plans similar to the one in Connolly, the Ninth Circuit's result was wrong.

This interpretation, however, lacks support in the Act's history and purposes. First, whether plans of this sort were regarded as defined contribution plans before Congress used the term "defined contribution plan" in ERISA is not clear. Although the plan had a fixed contribution rate, it also had a fixed benefit rate. The trustees set a given "pension factor" that was used to compute every retiree's benefit. On the basis of the pension factor and his or her service record, any employee could foresee the potential benefit. That benefit was awarded regardless of whether contributions to support the particular benefit for the particular employee had actually been made. ${ }^{91}$ Further, during collective bargaining the required contributions by employers are certainly approached with at least a rough notion of the benefit that will ultimately be paid. Fimally, the final benefit amount clearly does not simply "happen" over the years as the fund grows; rather, the final benefit amount is fixed by the affirmative act of the trustees long before the plan's actual contributions and experience are known. ${ }^{92}$ It may, then, be most appropriate to characterize these plans as hybrids between defined contribution and defined benefit plans. ${ }^{93}$

If such plans must be characterized, the focus should be upon which factor would be adjusted in the event of a deficiency or surplusthe benefits or the contributions. If the benefits are the usual variable, the plan could be called a defined contribution plan; if contributions are the usual variable, the defined benefit label may be more suitable.94

90. See text accompanying notes $62-63$ supra.

91. 581 F.2d at 733 .

Because the Fund made the same payments to each employee who qualified for a pension and retired at the same age, rather than establishing an individual account for each employee tied to the amount of employer contributions attributable to his period of service, the plan provided a "defined benefit."

International Bhd. of Teamsters v. Daniel, 99 S. Ct. 790, 794 n.3 (1979).

92. Employee reliance thus becomes an issue. If the employee is told only that he or she will receive the sum total of enployer contributions plus or minus a figure refiecting overall plan performance, he or she will probably not rely on the promise to the same degree as he or she would rely on a statement that benefits for $\mathrm{X}$ years of service are \$Y.

93. "These plans possess the characteristics of both fixed contributions and fixed benefits. The enployer is required . . . to contribute a certain amount . . . [and] the plan . . . specifies a definite scale of benefits . ..." J. Melone 20. See also D. MCGill 97; F. PoMERANZ, supra note 17 , at $6-7$.

94. F. POMERANZ, supra note 17, at 96. Some prefer to describe these plans as "target benefit plans." See Brief for Appellees 29-30; Oversight of ERISA, 1977. Hearings on S. 2125 Before the Subcomm. on Labor of the Senate Comm. on Human Resources, 95th Cong., 1st Sess. 179 (1977). In these plans, a target benefit is set and then contributions are calculated in order to achieve the benefit. The actual benefit paid is the amount the contributions support through earnings, plan 
Given this uncertainty, the tenuous argument that the term "defined contribution plan" referred to plans like the Operating Engineers' plan is weakened significantly. An ambiguous nonstatutory ineaning should not be sufficient to overcome explicit statutory definition. ${ }^{95}$

Second, if Congress intended that a typical multiemployer plan was to be excluded from the insurance program, one would expect some indication of that intention in the legislative history. In fact, no statements in the legislative history support this conclusion. On the contrary, a Senate committee report on an early version of the Act stated:

A collective bargaining plan where defined benefits are determined under a process in which the employers in the aggregate have a voice (e.g., under . . . the [Taft-Hartley] Act . . .) in the determination of the forms and levels of benefits, is not to be treated as a money purchase plan for these purposes (in the insurance provisions and elsewhere under the committee bill where distmctions are made between defined benefit plans and money purchase or other kinds of defined contributions plans), even though the collective bargaining agreeinent may specify only the level of employer contributions into the plan. Thus, these collective bargaining plans are covered by the insurance program. ${ }^{96}$

While there are no equally exphicit statements later in the record, there are no statements noting any change in this approach. Instead, the general policy apparently was to give multiemployer plan employees the same protection as other einployees. Senator Javits, a principal sponsor of ERISA, in explaining the delay in mandatory insurance coverage for inultiemployer plans, ${ }^{97}$ observed that " $[t]$ he conferees had no intention whatsoever of treating workers in these plans as 'second class citizens' and are determined that benefits be fully protected to the statutory limits regardless of the type of plan involved."98 This approach is also

experience, etc. See M. CANAN, supra note 41, § 3.52, at 94; E. AllEN, JR., supra note 9, at 34 n.4. This does not assist in resolving the Title IV question, however, since there is no reference to such plans in Title IV.

95. The courts inust "give effect to the intent of Congress, and in doing so our first reference is . . . to the literal meaning of words employed." Flora v. United States, 357 U.S. 63, 65 (1958).

96. S. REP. No. 93-383, 93d Cong., 1st Sess. 81 (1973), reprinted in 1 LEG. HIST. 1063, 1149 (1976). This report discusses S. 1179, the Senate Finance Committee's version of the bill. This version was several steps removed from the final bill: S. 1179 and S. 4 were combined into H.R. 4200 , the Senate's final version; this went to conference with H.R. 2, the House's final version. There was, however, never any repudiation of the statement that Taft-Hartley plans were subject to Title IV. A staff analysis of the differences between the two Senate bills inakes no mention of different attitudes about Taft-Hartley plans, 119 CoNG. REC. 30,134, 30,136-37 (1973), reprinted in 2 LEG. HIST. 1718, 1723-26, and the debate on the two bills contains no discussion on this point. It would seem that if the Finance Committee felt strongly enough about this provision to mention it in its report, some mention would have been made if the provision were changed.

97. See note 42 supra and accompanying text.

98. 120 CONG. REC. 29,940-41 (1974), reprinted in 3 LEG. HIST. 4767. 
supported by the Title IV provisions specifically designed to address the problems of multiemployer plans. These provisions would find litthe use if the typical multiemployer plan were excluded from Title IV. ${ }^{99}$

Finally, as the Nimth Circuit observed, the mclusion of Connollytype plans under Title IV coverage is consistent with Congress' overall goals in passing ERISA. ${ }^{100}$ Congress was extremely concerned about the loss of einployee pension benefits as a result of plan termination and enacted Title IV with the purpose of insuring that benefits would be paid even if the plans terminated. ${ }^{101}$ Those plans specifically excluded from Title IV coverage ${ }^{102}$ cannot fall short of promised benefits since they promise no benefit other than whatever can be paid. ${ }^{103}$ Plans like the Connolly plan do set benefits; 104 in doing so, they run the risk of being unable to provide promised benefits because they have funded benefits for past service, promised overgenerous benefits or experienced unexpected declines in contributions. ${ }^{105}$ Liability for benefits, then, is consistent with the treatment afforded all otler plans that set a benefit and could conceivably fail to provide it. ${ }^{106}$

Although the Nimth Circuit did not find it necessary to rely on ERISA section 4021(c)(1), ${ }^{107}$ that section also supports the result. The district court, holding that the benefits are not set by employer representatives but by trustees, apparently relied on the cases that emphasize the independence of the trustees. ${ }^{108}$ However, a degree of imdependence from the employers' control does not mean that the employerappointed trustees are not the employers' representatives. The TaftHartley Act refers to trustees as "the representatives of the employers and the representatives of employees." 109 Section 4021(c)(1)'s reference

99. See, e.g., 29 U.S.C. $\S \S 1305(a), 1306,1363,1364$ (1976).

100. 581 F.2d at 733 .

101. Throughout the committee reports and debates repeated reference was made to the loss of $\$ 49$ million in pension benefits of 19,400 employees caused by the closing of the Studebaker factory in Indiana, and to similar losses by employees elsewhere. See, e.g., S. REP. No. 93-383, 93d Cong., 1st Sess. 17 (1973), reprinted in 1 LEG. HIST. I085; H.R. REP. No. 93-799, 93d Cong., 2d Sess. 13 (1974), reprinted in 2 LEG. Hist. 2602; 120 CONG. REC. 29,194, 29,208, 29,213, 29,93435, 29,949-51, 29,952-54 (1974). See also Nachman Corp. v. PBGC, 592 F.2d 947 (7th Cir.), cert. granted, 99 S. Ct. 2881 (1979).

102. See note 70 supra and accompanying text.

103. 581 F.2d at 733.

104. Brief for Appellant at 19, Connolly v. PBGC, 581 F.2d 729 (9th Cir. 1978). See note 91 supra and accompanying text.

105. 581 F.2d at 733-34.

106. Simgle employer defined benefit plans almost always have clauses limiting employer liability, yet the Act guarantees the benefit set in the plan and creates additional hability for the sponsor.

107. See note 78 supra and accompanying text.

108. See note 73 supra and accompanying text.

109. 29 U.S.C. $\$ 186(\mathrm{c})(5)(B)(1976)$. In construing the term "representative" with regard to 
to the employer or his representative is a direct parallel clearly referring to the trustees. 110

Given the language and imtent of ERISA, it is necessary to conclude that the typical multiemployer plan such as the one in Connolly is subject to Title IV's provisions, including the payment of premiums and possible employer hability for benefits upon termination. While it is true that this "force[s] upon the employer a greater obligation . . . than he had agreed to in his contract," 111 "this is precisely what the termination insurance provisions of the Act were intended to do."112

\section{Constitutional Challenge to Title IV's Retroactive Alteration of Contract Obligations}

\section{A. Title IV's Retroactive Effects on Employer Liability.}

ERISA's direct conflict with typical contractual provisions limiting liability for pension obligations to the contribution promised ${ }^{113}$ raises the question of ERISA's constitutionahity under fifth amendment due process clause standards. ${ }^{114}$ Although Title IV converted all plans

employee representatives, the Court held that "Congress intended that it include any person authorized by the employees to act for them in dealings with their employers." United States v. Ryan, 350 U.S. 299, 302 (1956).

110. Section 4021(c)(1) was apparently intended to confirm that Taft-Hartley plans would be covered by Title IV even if they had individual accounts. The only exception would be an individual account arrangement in which the employer had no role in determining the benefits. This protects einployers froin being held hable for the payinent of benefits that they had absolutely no voice in setting. Cf. S. REP. No. 93-383, 93d Cong., 1st Sess. 58 (1973), reprinted in 1 LEG. HiST. 1126 (sponsors of collectively bargamed plans not entitled to the exception from funding requireinents granted to money purchase and defined contribution plans; exceptions allowed only where employers had no voice in determining "levels and forms of benefits"). Of course, since the TaftHartley Act requires that the employers name half of the trustees, this exception would rarely arise. One possible application is to pension trusts that were established prior to the passage of the Taft-Hartley Act, since these trusts were unaffected by the Act and may, therefore, be controlled entirely by the unions. See note 12 supra.

111. 419 F. Supp. 737, 740 (C.D. Cal. 1976), rev'd and remanded, 581 F.2d 729 (9th Cir. 1978), cert. denied, 99 S. Ct. 1278 (1979).

112. 581 F.2d at 732.

113. See text accompanying note 23 supra \& note 55 supra and accompanying text. Single employer plans also invariably included clauses limiting employer hability to the amount in the pension fund. Nachman Corp. v. PBGC, 592 F.2d 947, 956 n.14 (7th Cir.), cert. granted, 99 S. Ct. 2881 (1979).

114. Constitutional objections to employer hability have been raised in several recent cases. The courts in Connolly v. PBGC, 581 F.2d 729 (9th Cir. 1978), cert. denied, 99 S. Ct. 1278 (1979), and PBGC v. Defoe Shipbuilding Co., [1978] 178 PENS. ReP. (BNA) D-15 (E.D. Mich.), appeal docketed, No. 78-1280 (6th Cir. Aug. 7, 1978), did not reach the issue. Several courts have denied constitutional challenges. See Nachman Corp. v. PBGC, 592 F.2d 947 (7th Cir.), cert. granted, 99 S. Ct. 2881 (1979); PBGC v. Ouimet Corp., 470 F. Supp. 945 (D. Mass, 1979); Lear Siegler, Inc. v. PBGC, [1979] 238 PENS. REP. (BNA) D-3 (E.D. Mich. 1979). See text accompanying notes 149-54 infra. 
under its coverage-single einployer and inultiemployer alike-c"from gratuities to corporate liabilities enforceable at law," 115 the change is more drastic for the multieinployer plan sponsor than for the single employer that sponsors a nonnegotiated, defined benefit plan. ${ }^{116}$ First, in the standard defined benefit plan, the einployer has agreed to provide a set benefit. Any clause limiting liability im some way contradicts that promise. In contrast, under Taft-Hartley agreements the limit on liability reflects, rather than contradicts, the einployer's promise, smce the employer merely promises contributions to a separate trust. Second, while the employer sponsoring a plan without union participation actually controls the benefit level and slould logicially bear responsibility for providing the benefits, the employer who is a party to a multiemployer agreement lias no direct control over the benefit levels set by the trustees. ${ }^{117}$ Imposition of liability for the benefits im the latter case creates liability without control, or in any case, liability with less control than im the single employer nonnegotiated plan. ${ }^{118}$ Third, control over events leadimg to deficits in multienployer plans is minimal. A participatimg employer can be held liable for deficits despite faithful compliance with contribution requirements when another einployer's withdrawal or failure to contribute causes funding deficiencies or plan termmation. ${ }^{119}$ Finally, by inclusion of the pension contribution level in collective bargaining, the amounts agreed upon become a part of what is likely a carefully balanced package. A change im the nature of

115. J. TREYNoR, supra note 44 , at 1.

116. See text accompanying note 62 supra. The comparison with single-employer defined benefit plans is used here because such plans are clearly covered by Title 1V, while other pension arrangements, such as profit-sharing, are not.

117. See notes 16-18 supra and accompanying text. Although the employers collectively appoint half of the trustees, the control available to the employers as a group or individually is limited. The trustees have independent duties to the trust and can ignore einployer instructions. See note 73 supra. In fact, an employer who agrees to contribute to an already established pension fund may be compelled to accept employer trustees already appointed by the other employers. See, e.g., Sheet Metal Workers Local 493, 234 N.L.R.B. No. 162 (1978).

118. Sponsors of single-employer Taft-Hartley plans could make the same argument. Control may be greater in a single einployer plan simce one employer appoints half of the trustees, but anything less than total control raises the objection.

119. For example, if some employers failed to contribute or to pay excise taxes, PBGC could seek ternination. See note 41 supra. Upon termination, liability is assessed on the basis of the required contributions over the past five years-regardless of whether the obligation was actually met. See note 43 supra.

A withdrawing employer inust pay for an appropriate share of the plan's obligations only if it is a "substantial employer," an employer whose contributions are greater than $10 \%$ of all employer contributions in either the two preceding plan years or the second and third preceding plan years. 29 U.S.C. \& 1301(2) (1976). When any nonsubstantial employer withdraws, there is no evaluation of the effect on the plan, or any assessment of liability. Thus, if it develops that termination is necessary later, other employers who remained in the plan bear the burden of unfunded benefits left by the withdrawing employer. See 29 U.S.C. $\$ 1363$ (1976). 
the obligation increases the total package for which the einployer is responsible. In summary, one commentator has described the liability as "retroactive, uncertain, and open-ended." 120

\section{B. Constitutional Standards Governing Retroactive Legislation.}

Constitutional challenges to non-criminal legislation with retroactive effects rest on either the due process clauses of the fifth and fourteenth amendinents ${ }^{121}$ or on the contracts clause. ${ }^{122}$ These provisions have been read to reflect a general constitutional policy agamst legislation with retroactive effects, ${ }^{123}$ based upon concern for the reliance placed on existing law, ${ }^{124}$ a desire to promote stability, ${ }^{125}$ and fear of abuse of power by legislative bodies, since retroactive statutes can be directed with favor or disfavor toward specific classes with greater ease than can prospective laws. ${ }^{26}$

Consistent with the notion of a single underlymg constitutional policy against retroactive legislation, commentators and courts until recently have suggested that a single test determined the constitutionahity of all legislative enactments, whether the challenge arose under the due process or contracts clauses. ${ }^{127}$ Recent contracts clause cases, however, indicate that a separate and stricter standard of review applies to state

120. Jett, The Path to Destruction of Taft-Hartley Pension Trusts: Mandatory "Defined Benefit Plan" Status, 28 LABOR L.J. 403, 408 (1977).

The liability is retroactive because it is based upon acts performed by the employer prior to the passage of ERISA. . . . The amount of liability is uncertain because it depends upon pension plan experience . . . . The liability is open-ended because it can never be liquidated at one time, unless the plan is terminated, until the last plan participant dies.

Id. Mr. Jett was counsel for the plaintiff trustees in Connolly.

121. "No person shall . . . be deprived of life, liberty, or property, without due process of law ..." U.S. CoNST. amend. V. "[N]or shall any State deprive any person of life, liberty, or property, without due process of law ...." U.S. ConST. amend. XIV.

122. "No State shall . . . pass any ... Law impairing the Obligation of Contracts ...." U.S. CoNST. art. 1, § 10. In recent times, challenges to state statutes with retroactive effects liave typically been made on the basis of both the contracts clause and the fourteenth amendment. See Slawson, Constitutional and Legislative Considerations in Retroactive Lawmaking, 48 CAL. L. REv. 216, 221 (1960).

123. See generally Hochman 692; Slawson, supra note 122.

124. See Hochman 692, 727. This factor is of particular importance when contractual rights are involved. See Slawson, supra note 122, at 233.

125. See Hochman 692-93.

126. J. NowAK, R. RotUNDA \& J. YOUNG, HANDBOOK ON CONSTITUTIONAL LAw 428 (1978); Hochman 693.

127. Allied Structural Steel Co. v. Spannaus, 438 U.S. 234, 259-60 (1978) (Brennan, J., dissenting); United States Trust Co. v. New Jersey, 431 U.S. 1, 61 (1977) (Breunan, J., dissenting); Nachnuan Corp. v. PBGC, 592 F.2d 947, 959 (7th Cir.), cert. granted, 99 S. Ct. 2881 (1979); Greenblatt, Judicial Limitations on Retroactive Civil Legislation, 51 Nw. U.L. REv. 540, 543 (1956); Hale, The Supreme Court and the Contracts Clause: III, 57 HARv. L. REV. 852 passim (1944); see Hochman 695. Slawson, supra note 122 , at 221 . 
laws alleged to be in conflict with the contracts clause. ${ }^{128}$ Since ERISA is, of course, federal legislation, fifth amendment due process clause analysis is appropriate. 129

The Supreme Court's approach to due process challenges recognizes the "serious objections" to retroactivity, but the Court "has consistently held that not all retrospective statutes are unconstitutional, but

128. See Allied Structural Steel Co. v. Spannaus, 438 U.S. 234 (1978); United States Trust Co. v. New Jersey, 431 U.S. 1 (1977). The Allied Structural Steel case is of particular interest here since it involved a pension regulation statute, the Minnesota Private Pension Benefits Protection Act. The Act required pension plan sponsors that terminated plans or closed Minnesota plants or offices to pay a "pension funding charge" if the pension fund had insufficient assets to cover full pensions for employees who had worked at least 10 years. 438 U.S. at 238. The retroactivity objection arose because the 10 years included service prior to passage of the statute. "The Act required the employer to satisfy the deficiency by purchasing deferred annuities, payable to the employees at their normal retirement age." Id.

Holding the Minnesota statute unconstitutional, the Court einphasized the inportance of contractual stability, particularly with regard to pension funding. Id. at 246 . See uote 157 infra. In defending its statute, Minnesota could demonstrate no countervailing employee reliance interest since employees did not know of or rely on a 10-year vesting scheme when they accepted or continued employinent with Allied. 438 U.S. at 246 n.18. Further, although the State was not required to slow the existence of an emergency in order to justify the impairment of contracts by the law, the Court's insistence that the State show the existence of "a broad, generalized economic or social problem," id. at 250 , that would justify its entry into "an area never before subject to regulation by the State," id., placed a significant burden on the State to deinonstrate the necessity of the law. The Court's observation that the statute was not temporary in effect and did not provide for grace periods that would ameliorate its retroactive effects signaled the Court's willingness to engage in close scrutiny of the neans chosen by the state to solve whatever serious problems it could demonstrate. In short, the state had the burden to prove to the Court's satisfaction that the impairment was both necessary and reasonable. This reflects the approach taken in United States Trust Co. v. New Jersey, 431 U.S. 1 (1977), where the Court applied the reasonable and necessary test to hold unconstitutional a 1974 New Jersey statute retroactively repealing a covenant with New York that provided security for Port Autlority bonds. Id. at 25. The Court considered the statute unnecessary since other less drastic ineans were available, and unreasonable since the legislature could have foreseen the disadvantages of the covenant at the time it was passed. Id. at 29-32; $c$. Home Bldg. \& Loan Ass'n v. Blaisdell, 290 U.S. 398, 438 (1934) ("The question is . . . whether the legislation is addressed to a legitimate end and the measures taken are reasonable and appropriate to that end").

129. It is possible for those who wish to retain the coucept of a single standard to argue that the stricter test used in the recent contracts clause cases is the new test for all retroactivity cases. Cf. Nachman Corp. v. PBGC, 592 F.2d 947 (7th Cir.), cert. granted, 99 S. Ct. 2881 (1979) (recognition of two current standards and tlie concept of a single standard; no clioice of standard inade on grounds that the result would be the same under either standard). The likelihood of this result is diminislied by the recency of the Court's latest pronouncement of the due process test, Usery v. Turner Elkhorn Mining Co., 428 U.S. 1 (1976), and by tlie Court's recent references to the existence of two distinguishable tests. In United States Trust Co. v. New Jersey, 431 U.S. 1, 17 n. 13 (1977), the Court took care to contrast the due process standard with the contracts clause standard set forth in that opinion. Further, in Duke Power Co. v. Carolina Environmental Study Group, Inc., 438 U.S. 59 (1978), the Court contrasted the due process test with what was described as the "intermediate standard" of review employed in United States Trust Co. Id. at 82-83. Finally, lower federal courts have applied the due process standard to federal legislation and regulations without attempting to apply the stricter United States Trust Co. standards. See note 139 infra. See also Allied Structural Steel Co. v. Spannaus, 438 U.S. 234, 262-64 (1978) (Brennan, J., dissenting). 
only those which, upon a balancing of the considerations on both sides, are felt to be unreasonable." 130 Thus, in Fleming $v$. Rhodes, ${ }^{131}$ the Court noted that

[s] long as the Constitution authorizes the subsequently enacted legislation, the fact that its provisions limit or interfere with previously acquired rights does not condemn it. Immunity from federal regulation is not gained through forehanded contracts. Were it otherwise the paramount powers of Congress could be nullified by "prophetic discernment." 132

Only if the provisions are found to be "arbitrary and oppressive" do they violate the due process standard. ${ }^{133}$

The inost recent expression of this view came in Usery $v$. Turner Elkhorn Mining Co. ${ }^{134}$ in which the Court turned back a due process challenge to the Federal Coal Mine Health and Safety Act of 1969,135 which required payment of benefits on behalf of miners who contracted black lung disease, including miners who had left mine enployment prior to the passage of the Act. The mine operators placed principal reliance on Railroad Retirement Board v. Alton Railroad Co., ${ }^{136}$ in which the Court held unconstitutional a provision of the Railroad Re-

130. Hochman 694-95. Hochman described three main factors considered by the Court im retroactivity challeuges: (1) the nature and streugth of the public interest served by the statute, (2) the extent to which the statute modified or abrogated the asserted preenactment right and (3) the nature of the right altered by the statute. Id. 697 .

131. 331 U.S. 100 (1947).

132. Id. at 107 (footnote omitted).

133. Welch v. Henry, 305 U.S. 134, 147 (1938). See United States Trust Co. v. New Jersey, 431 U.S. 1, 17 n.13 (1977) ("The Due Process Clause . . generally does not prohibit retrospective civil legislation, unless the consequences are particularly "harsh and oppressive" "). See also Licliter v. United States, 334 U.S. 742 (1948) (removal of excess profits from wartime contracts); Cliase Securities Corp. v. Donaldson, 325 U.S. 304, 315-16 (1945) (alteration of statute of limitations); Norman v. Baltimore \& O. R.R., 294 U.S. 240, 307 (1935) (nullification of gold clauses in contracts between private individuals: "Contracts, however express, cannot fetter the constitutional authority of the Congress"); Calhoun v. Massie, 235 U.S. 170, 176-77 (1920) (attomey fees for Civil War claims restricted); Campbell v. Holt, 115 U.S. 620 (1885) (statute of limitations altered); Knox v. Lee, 79 U.S. [12 Wall.] 457, 549-52 (1870) (substitution of "greenhacks" as legal tender).

This principle has been apphed to protect the power to regulate interstate commerce from the restrictive effects of contracts made prior to congressional action. See United States v. Southern Pacific Co., 259 U.S. 214, 234-35 (1922) (antitrust); New York v. Umited States, 257 U.S. 591,600 01 (1922) (I.C.C. ratemaking authority); Philadelphia, B. \& W. R.R. v. Schubert, 224 U.S. 603 (1912) (employer liability for employee injuries contrary to contract); Louisville \& N. R.R. v. Mottley, 219 U.S. 467, 482-86 (1911) (railway passes); Atlantic Coast Lime R.R. v. Riverside Mills, 219 U.S. 186, 201-03 (1911) (railroad liability for damaged goods); Armour Packing Co. v. United States, 209 U.S. 56, 81-82 (1908) (railroad shipping rates); Addyston Pipe \& Steel Co. v. United States, 175 U.S. 211, 234-35 (1899) (antitrust).

134. 428 U.S. 1 (1976).

135. 30 U.S.C. $\$ \$ 901-941$ (1976).

136. 295 U.S. 330 (1935). 
tirement Act of $1934^{137}$ that required payment of pensions reflecting pre-Act employment to any former railroad employees who were reemployed after the Act's passage. The provision "plainly . . . alter[ed] contractual rights, [and] impose[d] for the future a burden never contemplated by either party when the earlier relation existed . . . . The provision [was] . . . retroactive in that it resurrect[ed] for new burdens transactions long since past and closed."138 The Act's provisions requiring pension funding for current employees for service prior to the Act's passage were also found unconstitutional. ${ }^{139}$

In Turner Elkhorn the Court insisted that the mine operators demonstrate that the legislation was "arbitrary and irrational."140 Retroactive effects alone would not meet this burden since "legislation readjusting rights and burdens is not unlawful solely because it upsets otlerwise settled expectations . . . even though the effect of the legislation is to impose a new duty or liability based on past acts." 141 It was recognized, lowever; that statutes witl retroactive effects inust meet due process tests that differ froin those for prospective statutes. ${ }^{142}$ The inquiry liere focused on whetler the mine owners knew that their employees could develop black lung disease and, if so, whether the employers acted in reliance on their nonliability for the disease's effects. The Court found that the mine owners knew of the dangers of black lung disease but that they could not show reliance on prior law simce it was not clear that the mine operators would have proceeded differently even if they lad known of their potential liability for employee disabilities caused by the disease. ${ }^{143}$ Despite the employers' knowledge of the

137. Pub. L. No. $73-485$, 48 Stat. 1283 (1934).

138. 295 U.S. at 349-50.

139. Id. at 353-54.

Although completed and compensated in full in conformity with the agreement of the parties... work done over a period of 30 years past . . . is to be the basis for further compulsory payment.

[A]rbitrary imposition of liability to pay again for services long simce rendered and fully compensated is not permissible. . . [T] here can be no constitutional justification for arbitrarily imposing millions of dollars of additional liabilities upon the carriers in respect of transactions long closed on a basis of cost with reference to whicl their rates were made and their fiscal affairs adjusted.

Id. In an alternative holding repudiated by later decisions, see NLRB v. Jones \& Laughlin Steel Corp., 301 U.S. 1 (1936), the Court held that the Act was beyond the congressional power to regulate interstate commerce. See 295 U.S. at 362-74. This liolding was of greater significance since it "raise[d] a barrier against all legislative aetion of this nature by declaring that the subject matter itself lies beyond the reach of the congressional authority to regulate interstate commerce," $i d$, at 375 (Hughes, C.J., dissenting), even if due process defects were corrected.

140. 428 U.S. 1,15 (1976).

141. Id. at 16.

142. Id. at 16-17.

143. Id. at 17. 
danger, the Court rejected the use of any deterrence or blameworthiness theory to justify retroactive liability. Rather, the statute was upheld as a "rational measure to spread the cost of the employees' disabilities to tlose who have profited from the fruits of their labor . . ." 144 Alton was distinguished on the grounds that the purpose of the Mine Safety Act was "to satisfy a specific need created by the dangerous conditions under which the former employee labored-to allocate to the mine operator an actual, measurable cost of his busmess"while the Alton statute simply "increas[ed] or supplement[ed] a former employee's salary to meet his generalized need for funds." 145

In summary, Turner Elkhorn suggests that the proper inquiry in cases involving retroactive liability pursuant to Congress' regulation of cominerce is whether the legislation rationally relates to a legitimate government purpose. ${ }^{146}$ Factors bearing on the rationality of the legislative scheme include the extent to which the harm souglit to be remedied by the statute can be traced to the party bearing the retroactive burden, that party's knowledge of the potential harm and the degree of the party's reliance on nonliability for the harm. ${ }^{147}$

144. Id. at 18. The employers claimed that the Act was arbitrary as it imposed liability on particular employers and not the industry as a whole, thus giving new employers an advantage over longtime operators with black lung liabilities. The Court deferred to Congress' clioice of a scheme to spread the costs. Id. at 18-19.

145. Id. at 19.

146. See J. NowaK, supra note 126 , at 433.

147. 428 U.S. at 17-18. Two recent series of cases illustrate further the approach used in evaluating statutes and regulations with retroactive effects. In Adams Nursing Home, Inc. v. Mathews, 548 F.2d 1077 (1st Cir. 1977), the nursing home challenged the constitutionality of an HEW decision to alter regulations allowing Medicare providers to use accelerated depreciation of capital assets in determining "reasonable cost" for reimbursement for Medicare services. Providers who left the program were held accountable for any difference between the accelerated depreciation used under the old regulations and the straight line depreciation required under the new regulations. The court found that the providers' conduct would probably have been the samc even in the absence of the regulation. Further, the providers' assumption that the regulations would not be changed was imappropriate in a field as heavily regulated as Medicare. See note $167 \mathrm{infra}$ and accompanying text. The constitutional challenge was denied. See also Summit Nursing Home, Inc. v. United States, 572 F.2d 737 (Ct. Cl. 1978); Springdale Convalescent Center v. Mathews, 545 F.2d 943 (5th Cir. 1977); Hazelwood Chromic \& Convalescent Hospital, Inc. v. Wemberger, 543 F.2d 703 (9th Cir. 1976). In Norfolk Baltimore \& Carolina Lines, Inc. v. Director, Office of Workers' Compensation Programs, 539 F.2d 378 (4th Cir. 1976), cert. denied, 429 U.S. 1078 (1977), the court rejected a due process retroactivity challenge to a 1972 amendment to the Longshorcmen's and Harbor Workers' Compensation Act that provided death benefits to survivors of employees who died from causes other than work-related injuries. The court relied on the expansive statement of congressional power to enact retroactive legislation in Fleming v. Rhodes, 331 U.S. 100, 107 (1947). See text accompanying note 132 supra. See also Nacirema Operating Co. v. Lynn, 577 F.2d 852 (3d Cir. 1978); State Ins. Fund v. Pesce, 548 F.2d 1112 (2d Cir. 1977). 


\section{Employers' Retroactive Liability for Benefits: Multiemployer Plan Benefit Insurance Under Due Process Analysis.}

Several recent cases raise the question of the constitutionality of Title IV's retroactive employer liability for benefits. ${ }^{48}$ In Nachman Corp. v. $P B G C,{ }^{149}$ the Seventh Circuit held constitutional the imposition of retroactive liability for benefits on the sponsor of a collectively bargained, single-employer defined benefit plan. ${ }^{150}$ The court found that retroactive liability was not an arbitrary or irrational means of achieving the goal of employee benefit protection. ${ }^{151}$ The decision empliasized that employee reliance on pension benefits outweighed employer reliance on nonliability, ${ }^{152}$ that holding the employer to pay the agreed-upon benefits was equitable ${ }^{153}$ and that the ERISA provisions moderated the impact of its retroactive features. ${ }^{154}$

The impact of retroactive liability on multiemployer plan sponsors is, however, arguably more severe than it is on single employer plan sponsors. ${ }^{155}$ Employer reliance on nonliability is probably stronger because of the diminished control over the fund and its eventual benefits. ${ }^{156}$ Further, the equity of holding employers to pay benefits at the level promised is reduced when the plan is not a true defined benefit plan and wlien no one employer has made a commitinent to provide a benefit. ${ }^{157}$ Additionally, the weakness of the legislative history on the

148. See note 114 supra.

149. 592 F.2d 947 (7th Cir.), cert. granted, 99 S. Ct. 2881 (1979).

150. Id.; see Nachman Corp. v. PBGC, 436 F. Supp. 1334, 1336 (N.D. Ill. 1977), rev'd, 592 F.2d 947 (7th Cir.), cert. granted, 99 S. Ct. 2881 (1979). See also PBGC v. Ouimet Corp., 470 F. Supp. 945 (D. Mass. 1979) (corporate member of control group held hable; constitutional challenge denicd); Lear Siegler, Inc. v. PBGC, [1979] 238 PENS. REP. (BNA) D-3 (E.D. Mich. 1979).

151. The use of the "arbitrary or irrational" test indicates that the court employed the due process test outlined in text accompanying notes 140-47 supra. The court, however, used analysis from the Allied Structural Stcel case to determime the constitutionality of Title IV's provisions. Although acknowledging that the contracts clause had no bearing on the case, the court observed that other authorities considered contracts clause precedent relevant in fifth amendment due process cases. 592 F.2d at 959 . See note 127 supra and accompanying text. Because the court was "convinced that ERISA withstands the scrutiny employed under the Contract[s] Clause cases," id, it saw no need to decide "whether the two clauses in fact impose ideutical restraints on legislative impairments of contracts," $l d$. Compare note 129 supra.

152. 592 F.2d at 961-62.

153. Id. at 962 .

154. Id. at $962-63$. These include the $30 \%$ of net worth limitations on an employer's hability, restrictions on the amount of benefits guaranteed and the still unadopted employer insurance program. Id. See note 43 supra.

155. See notes 113-20 supra and accompanying text.

156. See notes 117-18 supra and accompanying text.

157. By changing each sponsoring employer's obhigation from one to provide contributions to an obligation to provide benefits, ERISA arguably "grossly distort[s] the company's existing contractual relationships with its employees by superimposing retroactive obhgations upon the company substantially beyond the terms of its employment contracts." Allied Structural Steel Co. v. 
specific question of congressional intent to include multieinployer plans in Title IV could be seen as an indication that liability was imposed without adequate proof of or commitment to its necessity. ${ }^{158}$

Under Turner Elkhorn analysis these objections would be insufficient grounds for finding Title IV unconstitutional. Congress had plainly identified a problein it intended to solve. ${ }^{159}$ The question then is whether the imposition of retroactive liability is an arbitrary and irrational means of achieving this end. 160

The Turner Elkhorn Court first asked if the einployers knew of the threat of black lung disease. ${ }^{161}$ The purpose of an inquiry of this nature is to determine whetler Congress could have cliosen the employer as the one to bear the costs of remedying the harm on the grounds that the einployer was to blame for the harm. In Turner Elkhorn einployer knowledge was found, but this was not a sufficiently compelling reason to justify the retroactive liability. ${ }^{162}$ Even less "blame" can be found in the case of multiemployer plans. The blame for the harm, underfunded pensions, could not be placed entirely on the employers, since they presumably met their sole obligation by making the required contributions. ${ }^{163}$ The fund's management was out of their hands.

Spannaus, 438 U.S. 234, 249-50 (1978). Retroactive distortion of the contractual commitment is particularly worrisome when it concerns a matter as sensitive as pension funding. Id. at 246-47. See also City of Los Angeles v. Manhart, 435 U.S. 702, 721 (1978), in which the Court also recognized the sensitivity of pension funds to retroactive change, advising that "the rules that apply to these funds should not be applied retroactively unless the legislature has plainly commanded that result" (footnote omitted). ERISA, the Court noted, "paid careful attention to the problem of retroactivity . . . [by setting] a wide variety of effective dates for different provisions of the new law...." Id. at $721-22$ n.40.

158. See notes 96-99 supra and accompanying text. If the Allied Structural Steel test were used, the arguments presented here might well be conclusive. With the burden on the Congress to deinonstrate necessity in terms of a broad societal interest, one could deem a legislative history like the one here inadequate. Further, one could question the reasonableness of Congress' choice of mechanisms for correcting the problein. Since parties other than the einployers-for example, the unions or employees who pushed for high benefits, or the trustees who sct unreasonably high benefits-may bear part of the "blanie" for termination with inadequate funds, a "reasonable" scheme might distribute the costs anıong all of these parties. Finally, any retroactive liability whatsoever might be treated as unreasonable per se given the employer's reliance on nonliability and the arguably low level of employee reliance in plans without strictly defined benefits.

159. See note 101 supra and accompanying text.

160. See Nachman Corp. v. PBGC, 592 F.2d at 958-63.

161. See text accoinpanying note 143 supra.

162. See text accompanying note 143 supra.

163. A retroactive statute that operates to hold the parties to the original promises made is not unconstitutional. See Battaglia v. General Motors Corp., 169 F.2d 254 (2d Cir.), cert. denied, 335 U.S. 887 (1948) (Portal-to-Portal Act change in employee compensation scheme of Fair Labor Standards Act held constitutional); Campbell v. Holt, 115 U.S. 620, 628-30 (1885) (statute of limitations extension merely allowed enforcement of original contract); Ewell v. Daggs, 108 U.S. 143 (1883) (reliance on repealed usury defense misplaced because it was an attempt to escape contract obligations); Randall v. Kreiger, 90 U.S. [23 Wall.] 137, 149 (1874) (conveyance of land effective 
The next step is to ask if the employer placed justifiable reliance on the previous law when he took the actions that now give rise to liability. In Turner Elkhorn no such rehance could be shown. ${ }^{164}$ In the multiemployer plan situation, employer reliance is quite possible, simce employers may well have agreed to sponsor such plans, with their shared management and reduced control, only on the condition that they would bear no liability beyond the obligation to contribute. It is arguable, lowever, that any sucls employer reliance should be disregarded. First, as the Nachman court observed, employee reliance must be considered. ${ }^{165}$ While the employees could not justifiably rely on employer guarantees of benefits when no sucli guarantees existed, the employees undoubtedly relied on the payment of a pension benefit from the fund. ${ }^{166}$ Although employees would not necessarily rely on a set amount, since the benefit levels change, the benefit levels would provide a general idea to employees of the amount they could expect to receive upon retireinent and would induce them to forego making other retirement income arrangements. Employees would tend to identify the employers with the fund's promise to pay the benefits because the employers are the fund's principal source of income. This tendency would be encouraged if the employers, in past deficit situations, made virtually automatic contribution increases to support the benefits promised by the trustees. Sccond, the employers' reliance on nonliability for benefits was misplaced. The plans now subject to Title IV have long been governed by federal laws and regulations, imcluding the TaftHartley Act, the Internal Revenue Code and the Welfare and Pension Plan Disclosure Act of 1958. By agreeing to sponsor these plans, employers submitted to this extensive regulation and obtained, in ex-

by virtue of retroactive recognition of waiver of dower); Hochman 720 . While this doctrine speaks clearly to the limit of liability clauses in standard defined benefit plans, it is not dispositive regarding einployer liability in the defined contribution situation since there has been, in fact, no employer promise to provide a benefit. But the courts, along equitable principles, nay regard an employer's participation in the plan as an implicit recognition of the obligation to provide the benefit. See Hurd v. Hutnik, 419 F. Supp. 630, 655-56 (D.N.J. 1976).

164. See text accompanying note 143 supra.

165. Nachman Corp. v. PBGC, 592 F.2d at 960.

166. Employee reliance in ERISA-covered pension plans is stronger than the reliance in Allied Structural Steel or Alton R.R. Nachman Corp. v. PBGC, 592 F.2d at 961-62. In Allied Steel the employees had no 10-year vesting provisions and thns no basis to rely on early vesting until the legislature suddenly created vested rights. In Alton, pensions had not been bargained for or contracted for-Congress simply directed that they be created and funded. Obviously, the employees did not rely on this fortuitous act of Congress. Here, a pension obligation has been created, and benefit levels lave been set under an agreement to whicl the employer is a party. The pension is to be drawn from a fund of which the employers are the sole source of contribution income. Thus, employee reliance on the eventual payment of a pension by the employers is far inore jnstifiable than in either Allied Steel or Alton R.R. 
change, substantial tax advantages. It is well established that any entity choosing to enter a field already subject to heavy regulation accepts the possibility of retroactive change in the laws and regulations. ${ }^{167}$ At the very least, then, the extensive regulation of pension plans diminishes the strength of any claimed employer rehance so that it fails to overwhelm the employee reliance on full pension benefits.

Since einployer blameworthiness is imsufficient to compel retroactive einployer liability, ${ }^{168}$ but employer reliance here is insufficient to forbid it, the special concerns raised by retroactive liability statutes like this one and the Turner Elkhorn statute have no effect. The question then becoines the same one raised in any due process challenge to economic regulation: whether the statute is "a rational measure to spread the cost of the einployees' disabilities to those who have profited from the fruits of their labor .... [W] [Wether a broader cost-spreadimg scheine would have been wiser or more practical under the circumstances is not a question of constitutional dimension." 169 It is not at all difficult to conclude that Congress identified the employers-the fund's usual source of income-as the logical source of funds for elimination of underfunding and as the party best able to spread whatever costs that process involved. Although this choice may not have been a wise one, it was not one that violated the due process standard.

\section{Desirability of Title IV Coverage for Multiemployer Plans ANd Proposed Reforms}

\section{A. Impact of Title IV on Multiemployer Plan Growth.}

Despite their resistance to statutory construction and constitutional challenges, Title IV's multiemployer plan provisions are not nccessarily here to stay. ERISA's framers did not intend to regulate pension plans in a manner that would make plan sponsorship undesirable. On the contrary, Congress hoped to encourage plan growth so that more workers would receive pension coverage. 170 Disruptive regulation should have been avoided particularly in the case of multiem-

167. The leading case is Federal Hous. Administration v. Darlington, Inc., 358 U.S. 84 (1958), in which the Court said that "those who do business in the regulated field cannot object if the legislative scheme is buttressed by subsequent amendments to achieve the legislative aim." Id. at 91. See also Veix v. Sixth Ward Bldg. \& Loan Ass'n, 310 U.S. 32 (1940); Norman v. Baltimore \& O. R.R., 294 U.S. 240, 307-08 (1935); Summit Nursing Home, Inc. v. United States, 572 F.2d 737 (Ct. Cl. 1978); Ames v. Merrill, Lynch, Pierce, Fenner \& Smith, Inc., 567 F.2d 1174, 1179 (2d Cir. 1977); Adams Nursing Home, Inc. v. Mathews, 548 F.2d 1077 (1st Cir. 1977); Hazelwood Chronic \& Convalescent Hosp., Inc. v. Weinberger, 543 F.2d 703 (9th Cir. 1976).

168. Usery v. Turner Elkhorn Mining Co., 428 U.S. 1, 17-18 (1976).

169. Id. at 18-19.

170. See text accompanying note 34 supra. 
ployer Taft-Hartley plans. These plans were popular with employers, unions and employees because of the advantages they offered each group, ${ }^{171}$ and because of the absence of any other means of plan organization that met the unique requirements of these groups. ${ }^{172}$ Furthermore, these plans rarely terminated because of their broad bases ${ }^{173}$ and their ability to use benefit reductions and mcreased contribution levels to correct deficits. ${ }^{174}$

ERISA altered this system drastically by creating liability for benefits despite contractual provisions to the contrary. Employers are less mclimed to jom multiemployer plans on this ground alone, given the lack of employer control over benefits ${ }^{175}$ and the effect potential liability may have on the employer's ability to obtam credit. ${ }^{176}$ In addition, however, the trustees are no longer as free to reduce benefits when the plan cannot support the benefit with the current contributions. ERISA requires vesting of benefits ${ }^{177}$ and restricts benefit reductions, ${ }^{178}$ thereby making correction of underfunding problems and avoidance of termination more difficult. The only "corrective device" remaining is the request for additional employer contributions, backed up by the threat of employer liability if the plan's problems are not corrected. Thus, the price for stable benefit levels is decreased plan fiexibility.

171. See notes 24-33 supra and accompanying text.

172. For workers in industries with highly mobile work forces, a multiemployer arrangement is the best if not tbe only means of obtaining an einployer-funded pension. Some alternative retirement income devices are not well suited to sponsorship by more than one einployer. For example, a profit-sharing plan would have no single profit pool to assess for contributions. Employers in these highly competitive industries would be unlikely to agree to an industry- or areawide computation of profit since this would penalize the more profitable companies to the benefit of their less profitable competitors and their employees. The alternatives are not as advantageous as the current systein. For example, individual retirement accounts (IRAs) would provide a benefit, but, if left to employee mitiative, broad employee participation is less likely. Further, the employer loses tax deductions, and the union loses its involvement. Even if the employer or the union and employer set up the IRAs, the employer's tax advantage is less than he would have under a qualified retirement plan. See Wangard, Selecting a Qualified Plan After ERISA: The Alternatives, Problems and Costs, $43 \mathrm{~J}$. TAX. 145, 145 (1975). Despite these disadvantages, IRAs are increasingly attractive as a result of ERISA's regulations. N. Levin 348.

173. See note 30 supra and accompanying text.

174. PBGC STUDY 4, 51-52.

175. See note 117 supra and accompanying text.

176. The PBGC's claims on employer assets enjoy a precedence, similar to federal tax liens, over those of other creditors. See 29 U.S.C. $§ 1368$ (c) (1976). Unfunded vested liabihties must be recorded on financial statements, however, only if a plan is to be terminated or when there is convincing evidence of impending termination. See F. POMERANz, supra note 17, at 114. Any hint of employer liability would undoubtedly affect the company's ability to receive credit. See Erlenborn, The Future of Private Pensions, in Private and Public Pension Plans: The New Legislation and Future Prospects 36, 40 (1975).

177. See PBGC STUDY 53 n.10. See note 35 supra.

178. ERISA allows multiemployer plans to reduce benefits retroactively for up to two years, but restricts the other benefit reductions fornerly used to avoid termination. 
Given these restrictions, multiemployer plans are more likely to lave unfunded liabilities. This leads to higher costs to the employer as the plan attempts to reduce the underfunding without lowering benefits. Employers who prefer to avoid these higher costs and the potential liability will take one of several steps. First, if they are not "substantial employers," they may witlidraw from the plan without being assessed any liability for underfunding. ${ }^{179}$ As a result, employers remaining in the plan are left witl even greater burdens, and early withdrawal, even with some liability, in order to avoid being among the last to leave the plan, is encouraged. Second, the employer can terminate the entire plan and let the PBGC take over the payment of benefits. ${ }^{180}$ Although the employer will be liable for up to thirty percent of net wortl for unfunded benefits, the employer may prefer this liability to continuing under the plan if the costs of supporting the plan in tle long run appear to exceed the thirty percent limit. ${ }^{181}$

The employees and the union inay accept or even encourage termination. The retired workers' benefits will be paid by the PBGC. Current employees who liave been paymg a large portion of their total compensation for the pensions of retirees can now seek these same funds either as direct wages or create an "actives only" pension plan, unburdened by obligations to past employees and thus capable of providing the same or higher benefits at a lower cost. ${ }^{182}$

ERISA, then, creates clear incentives for employers to terminate plans completely or to conclude their coinpany's participation through withdrawal. If neither of these actions is possible, employers will use whatever influence they liave over trustees to avoid any increased coinmitments to ongoimg plans, sucl as higher benefits, which increase potential liabilities. ${ }^{183}$ In addition, any conipany not presently a party to a plan will probably resist proposals to join one ${ }^{184}$ by pushing instead

179. See note 119 supra.

180. See note 41 supra.

181. PBGC STUDY 51.

182. Id.

183. See N. LEvin 347. The risk of liability increases every time benefits are raised since the change in the benefit level increases past service liabilities. See also Hurd, Defined Benefit PlansAn Endangered Species?, 114 Trusts AND EsTaTES 206, 208 (1975). The ability of the employer to influence benefit levels depends on the ability to influence the trustees. Legally, the trustees are independent, see note 73 supra, but if the employer faces liability, attempts may be made to increase direct control.

184. S. Rep. No. 95-570, 95th Cong., 1st Sess. 3 (1977) (quoting PBGC, Potential MultiemPLOYer Plan Liabilities UNDer TITLe IV of ERISA (1977), reprinted in PBGC Study app. I, at 7), reprinted in [1977] U.S. CODE CONG. \& AD. NEwS 4128, 4130; N. LEVIN 348. A variation on this theme involves employers' avoiding work projects in areas of the country that will bring them in the jurisdiction of a different pension plan. If the employer qualifies as a substantial employer, when the job is completed and the employer ceases to contribute to the plan, ERISA treats the 
for some other form of compensation for union employees ${ }^{185}$ or by avoiding the use of union employees. ${ }^{186}$

The final result is that plan adoption, retention and growth are less likely after ERISA than before ERISA. Correspondingly, as withdrawals and terminations become more common because of ERISA's provisions, the cost to the PBGC will imcrease, as it niust pay benefits to increased numbers of einployees whose plans have terminated. A 1977 PBGC report found that multiemployer plans covering 1.3 million workers were experiencing difficulties that could lead to termination over the next ten years. The cost to PBGC's insurance program, after employer liability was collected, would be $\$ 4.8$ billion. To cover such costs, PBGC would need to imcrease its multienployer premiums from the current fifty cents per participant per year to eighty dollars per participant per year. ${ }^{187}$ While the financial difficulties thenselves are not necessarily attributable to ERISA, ${ }^{188}$ ERISA did impose restrictions on the ability of the plans to respond to economic difficulties, and it created incentives for plan termination.

\section{B. Proposed Reforms.}

1. The Coimolly Solution: Multiemployer Plans Exempt from Title $I V$. As a solution to these difficulties, the Connolly plaintiffs would simply read the multiemployer Taft-Hartley plan out of Title IV by classifying such plans as defined contribution plans. If statutory construction of the existing statute fails to accomphish this, an amendment could easily do so. The prospects for plan contmuance and growth would be better than in the current situation, simce the employer's contingent liability, and hence the problems caused by the withdrawal of employers, would be eliminated. Not all ERISA burdens would be

employer's action as a withdrawal and requires the employer to post a bond or place funds in escrow to cover any potential liabilities for five years. This extra cost will make a bid by employers from outside the area prohibitively expensive. See Oversight of ERISA, supra note 94, at 17778; N. LeviN 339; Diamond, Funding Liability Under Union Pension Plans, J. Accountancy 7478 (Sept. 1975). The PBGC has proposed changes to deal with this problem. See PBGC STUDY 99-100.

185. Higher wages are an example. Current employees unay prefer a higher wage at present rather than diversion of a portion of their total compensation to fund pensions for retirees.

186. There is an incentive to use nonunion shops or "double-breasted" operations in order to avoid the union fund. See Oversight of ERISA, supra note 94, at 230-31 (testimony of Matthew Lind, PBGC Director); H. REP. No. 95-706, 95th Cong., 1st Sess. 5 (1977).

187. PBGC Study 1-2; see PBGC, Potential Multiemployer Plan Liabilities Under TITLE IV OF ERISA (1977), reprinted in PBGC STUDY app. I.

188. Termination has become more likely in certain declining industries, where lower current payrolls and contributions cannot adequately fund the pension commitments unade to work forces once larger and now retired or soon to retire. Oversight of ERISA, supra note 94, at 228-29 (testimony of Matthew Lind); PBGC STUDY 4. 
lifted, however; the sponsors would still be subject to the participation, vesting, fiduciary responsibility, reporting, disclosure and funding requirements. ${ }^{189}$ But any added costs froin these provisions would simply be assessed against the trust fund, so that the same fixed contribution rate would provide a sinaller benefit. As long as the einployer is not liable for the benefit, the question of higher costs is passed to the trustees im their benefit level determination or is set aside until the next contract comes up for collective bargaining, when deficiencies under the funding standards would be addressed. The einployer would not face the impact of the costs until there was a contractual agreement for increased contributions.

Clearly, this alternative would reduce employee protection by ending the PBGC's guarantee of benefits. It is arguable, of course, that employees should expect no set pension benefit, since in the typical multieinployer situation mobile workers are accepting the best pension arrangeinent possible, albeit witl uncertain benefits not guaranteed by any one of the employers they work for during their lifetimes. The trustees do, lowever, set a benefit, and the employees presumably rely on that alnount in planning for their retirement. This expectation is what Congress hoped to protect by including such plans in Title IV. ${ }^{190}$

The security of benefits even without Title IV would seemingly remaim reasonably higli. The pre-ERISA Taft-Hartley plan was less prone to failure than a single employer plan, ${ }^{191}$ and the ERISA funding requireinents sliould insure stronger plans. Those saine funding requirements, lowever, in coinbination witl ERISA vesting requirements, increase costs and restrict the reinedial benefit reductions formerly available under the plan. Exclusion from Title IV would not discourage terminations attributable to these non-Title IV provisions. ${ }^{192}$ Further, pension plans in declining industries are exceptions to the general rule that multieinployer plans are economically sound and stable. Elimination of Title IV coverage cannot change the fortunes of the industry or inake termination of plans less likely, but it will end PBGC's benefit guarantee. This is a serious disadvantage in direct conflict with Congress' desire to protect einployee benefits upon plan termination, and militates for the continuation of some sort of benefit-

189. The funding provisions enforce the contribution requirements and insure that contributions and benefits are reconciled when the contract period ends. They do not, however, alter liability at termination. See note 36 supra.

190. See note 101 supra and accompanying text.

191. Unless the entire industry is in decline, the imclusion of many employers makes termination less likely than when the plan is dependent on the fortunes of a simgle employer. See note 30 supra and accompanying text.

192. See notes 177-78 supra and accompanying text. 
insurance scheme if it can avoid negative effects on plan growth in other industries.

2. PBGC Proposals. In response to the 1977 report predicting nuinerous multiemployer plan terminations at great expense to the PBGC, Congress required the PBGC to prepare proposals for the reform of ERISA's multiemployer plan provisions. ${ }^{193}$ The PBGC produced a study that analyzed the problems anticipated under ERISA and offered options for their correction. ${ }^{194}$ The study proposed changes in solne ERISA provisions outside Title IV. ${ }^{195}$ The mam focus, however, was on Title IV. The report explored options imcluding the imposition of employer liability upon withdrawal,196 a program for reorganization of financially troubled plans ${ }^{197}$ and revised benefit guarantee levels combined with alterations in the employer liability provisions. ${ }^{198}$

The PBGC study advanced two basic alternative approaches to the problein of einployer liability. The first approach, which emphasized reduction of PBGC's exposure to loss, would have increased the employer's potential liability to $100 \%$ of net worth, ${ }^{199}$ while reducing the

193. Act of Dec. 19, 1977, Pub. L. No. 95-214, 91 Stat. 1501.

194. PBGC STUDY.

195. These include redefining "multiemployer plans" to cover more of the plans with the charactcristics usually attributed to such plans, id. 26-32; imposing stricter funding requirements by reducing amortization periods, limiting benefit increases during periods of shortfall, and imposing mininum contributions rates, id. 40; regulating mergers of plans and transfers of liabilities, id. 115-19; and restructuring PBGC's premiums to reflect PBGC's exposure to loss and the risk of termination, $i d$. 122-36.

196. See id. $94-114$.

197. Id. 65-69.

198. [T] he report presented five alternative approaches to termination guarantees and employcr liability which PBGC considered. They were as follows:

(1) employer bability for full vested benefits and reduced benefit guarantees,

(2) employer hability for guaranteed benefits only and reduced benefit guarantees,

(3) no cmployer liability and no beneflt guarantees,

(4) employer kability for guaranteed benefits only and reduced benefit guarantees only if the plan miposes withdrawal liability on withdrawing employers, otherwise, no bencfit guarantees and no employer liability, and

(5) employer hability only for the guaranteed benefits of retirees and those within five years of normal retirement, with benefit guarantees only for such participants.

Under these approaches, with the cxception of Program 3, employer liability would not be limited to 30 percent of net worth, i.e., the present statutory limit, but instead employers would continue to fund their share of the unfunded termination bability. Id. 73 (footnote omitted).

199. This approach includes proposal 1, supra note 198, in which the employer would be hable for up to $100 \%$ of his net worth for all vested benefits; and proposals 2 and 4, supra note 198, where the employer would be liable only for guaranteed benefits (with reduced guarantees). The rationalc for proposal 1 was that "employers would be encouraged to seek sound funding practices and both employcrs and the union would attempt to prevent termination becanse high hability could jeopardize the ability of participating employers to continue in busmess or to compete with nonparticipating employcrs." PBGC STUDY 74-75. Proposals 2 and 4 reduce guarantee levels in 
amount that the PBGC would guarantee. If a plan terminated with a deficit, the employees would receive less from the PBGC than they would under the current scheme, but whatever the PBGC paid out could be recovered from employers until their assets were exhausted. The second approach would have eliminated the PBGC's guarantees entirely and would also have eliminated employer liability. ${ }^{200}$ This alternative was acceptable to the PBGC only if adopted in combination with the plan reorganization and financial assistance proposals.201

The PBGC study was followed by recommendations ${ }^{202}$ that were largely mcorporated imto legislation submitted to Congress in bills imtroduced in both houses in May, 1979.203 Passage of this legislation would significantly alter the treatment of mnltiemployer plans under ERISA.204

The proposed legislation would deal with the problem of employer withdrawal by holding all withdrawing employers liable for their shares of the plan's unfunded vested obligations. ${ }^{205}$ This would encourage plan participation by decreasing the chances of termination upon withdrawal of an employer and the subsequent liability of remaining employers for the withdrawing employer's obligations.

The legislation approaches the problem of financially troubled plans by requiring reorganization to avoid termination. ${ }^{206}$ Plans that are classified as being under reorganization are subject to special fund-

the hope that "some of the potentially adverse impact of employer hability . . . [will] be mitigatcd." Id. 83.

200. Proposal 3, supra note 198, reflects this approach. See PBGC STUDY 85-88. The variation in proposal 5 would retain employer hability (increased to $100 \%$ of net worth) and PBGC guarantees for retirees only in order to provide "maximum benefit security to those participants most in need of retirement income security." Id. 89.

201. See id. 85.

202. The PBGC recommendations were issued in March, 1979. See "Recommendations Submitted to Congress by PBGC on Restructuring Multiemployer Plan Termination Insurance Program," [1979] 230 PENS. REP. (BNA) R-2 (Mar. 12, 1979).

203. S. 1076; H.R. 3904, 96th Cong., Ist Sess. (1979).

204. Insofar as the legislation, if passed, eliminates provisions that are particularly objectionable to plan sponsors, the incentive to raise statutory construction arguments similar to those in Connolly might be eliminated. The legislation itself, however, would not resolve the definitional questions raised.

205. See S. 1076, § 104 (proposing ERISA § 4201). A withdrawal occurs when an employer permanently ceases to have an obligation to contribute under the plan or perinanently ceases all covered operations under the plan. The withdrawal liability is determined by subtracting the total of plan assets and any outstanding withdrawal liability claims from the present value of all vested benefits, and then multiplying this number by a fraction that reflects the proportion of contributions attributable to the withdrawing employer over the prior five years. If this figure is less than the greater of $\$ 25,000$ or $.75 \%$ of the plan's unfunded vested babilities, there is no withdrawal liability.

206. Plans qualifying for reorganization would be identified by use of a "reorganization imdex," computed by subtracting the charges to the funding standard account from the "vested lia- 
ing requirements. ${ }^{207}$ Plans undergoing reorganization would be eligible for "overburden credits" that assist plans in which the active employees are outnumbered by retirees. ${ }^{208} \mathrm{~A}$ ineasure of pre-ERISA benefit reduction flexibility would be gained since these plans would be allowed to reduce or eliminate beneflts not in effect for at least five years, a step not always possible under ERISA's ordinary vesting rules. ${ }^{209}$

Perhaps the most notable change is the approach to plan termination. Under the new legislation, termination alone does not trigger PBGC payments to participants. PBGC funds become available ouly when a plan is insolvent. ${ }^{210}$ Further, the PBGC funds that are distributed to plans are in the form of loans to the plan ratlier than benefit payments. ${ }^{211}$ Insolvent plans may also reduce certain benefits. ${ }^{212}$ The

bilities charge." The vested liabilities charge is the amount necessary to amortize the plan's unfunded vested liabilities. If the result is greater than zero, the plan is in reorganization status.

207. The legislation would add ERISA $\S 4243$, creating a "minimum contribution requirement" (MCR) that would govern funding for plans in reorganization.

[Tlie MCR] would require that the negotiated contribution rate be sufficient to produce contributions equal to the "vested liabilities charge," if current levels of employment under the plan continued. The vested liabilities charge is the sum of: (1) the amount necessary to begin amortizing, over 10 years, the unfunded vested liabilities for benefits in pay status; and (2) the amount necessary to begin amortizing, over 25 years, the remaining unfunded vested liabilities.

Multiemployer Legislative Proposal Explanatory Statement, 125 CoNG. REC. S5321, S5322 (daily ed. May 3, 1979) (footnote omitted).

208. The overburden credit is designed to meet the needs of plans overburdened with retirees. The plan is defined as overburdened if:

(A) pay status participants under the plan constitute at least 50 percent of the plan's extended participant group; and (B) the rate of einployer contributions under the plan equals or exceeds the greater of the rate for the preceding plan year or the rate for the plan year prior to the first year that the plan was in reorganization.

S. 1076, § 104 (proposing ERISA § 4243(d)(2)). The credit, used for funding purposes, is coinputed by multiplying one-half of the average covered benefit payment for the plan year times the "overburden factor." The overburden factor is the "excess of pay status participants over all other persons in the extended participant group." Id. (proposing ERISA § 4243(d)(4)(F)).

209. A new ERISA section 4244 would allow the plan "to reduce or eliminate accrued benefits, attributable to employer contributions that, under section $4022 \mathrm{~A}(\mathrm{~b})$, are not guaranteeable by the corporation." Id. (proposing ERISA § 4244(a)(1)). Section 4022A(b) states that benefits in effect for less than five years are not guaranteeable. Id. $\S 102$ (proposing ERISA $\S 4022 \mathrm{~A}(\mathrm{~b})$ ).

210. Explanatory Statement, supra note 207, at S5324.

211. Both proposed section 4245 , dealing with insolvent plans, and section 4281 , dealing with insolvent terminated plans, allow the plan to obtain loans under proposed section 4261 "on sucl conditions as the corporation determines are equitable and appropriate to prevent unreasonable loss to the corporation with respect to the plan." S. 1076, § 104 (proposing ERISA § 4261(b)(1)). This means that while benefits will be paid at guarantee levels through PBGC funds, the PBGC will regain its funds if the financial health of the plan is restored so the plan can repay its loans.

212. "[B]enefit payments (other than basic benefits) under an insolvent inultiemployer plan that exceed the resource benefit level shall be suspended . . . . 'R]esource benefit level' ineans the level of monthly benefits determined . . . to be the highest level that can be paid out of the plan's available resources." Id. (proposing ERISA $\S \S 4245(\mathrm{a})$, (b)(2)). 
combimation of the withdrawal rules and the reorganization and financial assistance rules means that plans could be inaintained through employer withdrawal hability paynents, PBGC loans and reorganization. A true termination would occur only in limited instances. ${ }^{213}$ Even when termination occurred, employer contribution obligations or withdrawal obligations would continue, reorganization steps would be taken and the assistance available to insolvent plans could be provided if the plan qualified. ${ }^{214}$ There would, however, be no direct payinent of guaranteed benefits by the PBGC. With no payments by PBGC, there would be no need to inake a separate assessment on employers to cover PBGC's losses. 215

Other important provisions of the PBGC bill mclude stricter funding requirements, with shorter anortization periods; ${ }^{216}$ lower benefit guarantees; $; 17$ increased premiums; ${ }^{218}$ provisions regulating inergers and transfers between plans; ${ }^{219}$ and a redefinition of multienployer plans. ${ }^{220}$ The bill would also repeal section 4023 of ERISA, eliminating the prograin for contingent einployer liability insurance. 221

The legislative package offered by the PBGC strikes a balance between the potentially conflicting objectives of an insurance prograin. The elimination of einployer termination hability, the protection of nonwithdrawing employers from the liabilities of withdrawing employers and the refusal to release enployers from contribution obligations should decrease the incentives to terminate. The reduced guarantee levels and higher premiums and the use of loans rather than direct benefit payments are designed to protect the PBGC's solvency. Of course, some sacrifice has been made in terms of einployee benefit protection, since guarantees are lower and some benefits may be reduced. These

213. Termination would occur when a plan was amended so participants would receive no credit for service with employers, or when all employers withdrew, or when the plan was amended to become a defined contribution plan. Id. § 103 (proposing ERISA § 4041A(a)).

214. Explanatory Statement, supra note 207, at S5324.

215. The new legislation makes the employer liability calculations set forth at ERISA § 4064, 29 U.S.C. $\S 1364$ (1976), mapplicable to multiemployer plans. S. 1076, § 402(i). There are no comparable provisions creating an employer obligation to repay the PBGC for funds it provides to insolvent plans. Of course, employer obligations may be greater than agreed to, since a withdrawing or terminating employer remains obliged to contribute amounts necessary to fund vested, guaranteed benefits.

216. S. $1076, \S 202$.

217. Id. $\S 102$.

218. Id. $\S 105$. The premiums would increase over a five-year period to $\$ 2.60$, the same as for single employer plans. Id.

219. Id. \& 104 .

220. Id. $\S 206$. Multiemployer plans would be defined as those to which more than one employer is required to contribute pursuant to collective bargaining agreements. Id.

221. Id. $\S 107$. 
losses, however, are not necessarily major ones. First, the pre-ERISA multiemployer plan was stable. When the Title IV provisions blamed for upsetting plan stability are removed, stability should imcrease,222 and with increased stability coines greater security for employee benefits. Unlike the Connolly solution, however, employees would retain protection. Protective provisions outside of Title IV, includimg vesting, funding and fiduciary responsibility, would still be in force; additionally, the plan reorganization and loan provisions would be available. The loan and reorganization provisions should be especially useful in the declining industry situation, unuch im the manner that the PBGC's discretionary authority has been used to protect workers in such industries.223 Benefit reductions, although permitted, would remaim restricted even for plans in deep financial trouble. Of course, if einployees desire greater protection, imcluding commitments by employers to assume full hability for promised benefits, they could negotiate agreeinents of that nature with the einployers.

\section{ConCLusion}

Congress' passage of the benefit insurance program of ERISA's Title IV indicated the strong congressional commitment to protection of employees' pension expectations. The emphasis on benefit protection, however, should not obscure an equally important goal: the continued encourageinent of employer sponsorship of pension plans. While the loss of benefits through termination of unfunded plans deprives the employee of retirement mcome in a sudden and dramatic fashion, the loss can be every bit as substantial if employers never establish plans, are unwilling to make financial commitments to the plan for fear of unknown liability, or terminate potentially viable plans to avoid future liability and to take advantage of the insurance program. It is appropriate then, even after concluding that Congress did intend to include multiemployer plans in Title IV and that it could do so without constitutional objection, to ask whether the decision was a wise one. The PBGC's studies indicate that some sort of change is necessary if the collapse of the pension plan insurance system is to be avoided. This offers Congress an opportumity to eliminate those portions of Title IV that unduly discourage plan sponsorship. At the same tine, by mamtaining supervision and control over plans under a revised Title IV providing for reorganization and loans, employee benefit protection would be superior to the pre-ERISA plan. This compromise between the pre-

222. PBGC STUDY 86.

223. See id. app. IX. 
ERISA system that encouraged widespread participation and the ERISA system that attempts to guarantee benefits could better serve the overall goal of providing secure benefits for as many workers as possible.

James $N$. Leik 